Pesq. Vet. Bras. 35(Supl.1):69-83, dezembro 2015 DOI: $10.1590 / \mathrm{S} 0100-736 \mathrm{X} 2015001300012$

\title{
Morfologia do escroto, do testículo e das vias espermáticas de Metachirus nudicaudatus (Geoffroy, 1803), Didelphidae-Marsupialia ${ }^{1}$
}

\author{
Suely F. Costa ${ }^{2 *}$, José C. Nogueira ${ }^{3}$, Bruno A. Soares ${ }^{4}$, Natália A. Ambrósio² , Amália \\ S. Chaves ${ }^{2}$, Leandra Q. de Melo ${ }^{2}$ e Márcio G. Zangeronimo ${ }^{2}$
}

\begin{abstract}
Costa S.F., Nogueira J.C., Soares B.A., Ambrósio N.A., Chaves A.S., Melo L.Q. \& Zangeronimo M.G. 2015. [Morphology of scrotum and testicle, and spermatic pathways of Metachirus nudicaudatus (Geoffroy, 1803), Didelphidae-Marsupialia.] Morfologia do escroto, do testículo e das vias espermáticas de Metachirus nudicaudatus (Geoffroy, 1803), Didelphidae-Marsupialia. Pesquisa Veterinária Brasileira 35(Supl.1):69-83. Setor de Morfologia Animal, Departamento de Medicina Veterinária, Universidade Federal de Lavras, Campus UFLA, Lavras, MG 37200-000, Brazil. E-mail: sfcosta@dmv.ufla.br

Gonads and sperm pathways of five adult male Metachirus nudicaudatus in the reproductive phase were used to describe the morphology of scrotum, testicle, and spermatic tract. $M$. nudicaudatus has a scrotum pre-penis which contains the testicles permanently. The scrotal skin is not pigmented and has few hairs and glands. The parietal vaginal tunic is slightly pigmented. The testicles are oval and connected to the epididymis by testicular-epididymal pedicle; they are surrounded externally by the testicular capsule and supported by a stroma of connective nature. Interstitial cells are the predominant elements in abundant intertubular tissue. The seminiferous tubules are wide, meandering and surrounded by a fibro-elastic coat, containing myoid cells. The seminiferous epithelium is composed of spermatogenic cells and Sertoli cells interspersed. The seminiferous tubules converge toward the end of the testis capitata, getting coated only support cells, featuring a transition region between the seminiferous tubules and straight tubules, occupied by a type "valve" structure that partially blocks the tubular lumen. Straight tubules together to form a single efferent ductule, which runs a small intra-testicular extent, penetrates through the tunica and the pedicle testis-epididymis. The flexuosa part of the efferent ductule forms a separate lobe in the medial part of the body of the epididymis. The epididymis is enveloped by a capsule and epididymal comprising the epididymal duct, which is quite entangled. The epididymal duct is lined by pseudostratified columnar epithelium with simple principal, basal, apical and "clear halo" cells. The main cells are prevalent and have morphological and histochemical differing characteristics along the duct, enabling to characterize nine different epididymal areas. In the lumen of the seventh area (top of tail) that starts the pairing of sperm. This phenomenon coincides well with morphological change and a larger amount of neutral muco-substances is secreted in that area. Vas deferens has three parts: fair-epididymal, abdominal and funicular part, based on histological and histochemical changes of the epithelium and surrounding components. The vas deferens has no bulb and even crosses the ureter before flowing into the urethra. The spermatic cord contains the vas deferens, testicular artery and veins, lymphatic vessels, nerves and developed cremaster muscle. Its components have structural changes in the proximal, middle and distal region, with a peculiar admirable network.
\end{abstract}

INDEX TERMS: Scrotum, testicle, spermatic pathways, Metachirus nudicaudatus, Didelphidae, Marsupialia, Jupati, epididymis, histology, male genital system.

\footnotetext{
${ }^{1}$ Recebido em 29 de maio de 2015.

Aceito para publicação em 14 de dezembro de 2015.

${ }^{2}$ Departamento de Medicina Veterinária, Universidade Federal de Lavras (UFLA), Av. Doutor Sylvio Menicucci 1001, Kennedy, Lavras, MG 37200-000, Brasil. *Autor para correspondência: sfcosta@dmv.ufla.br

${ }^{3}$ Setor de Morfologia, Instituto de Ciências Biológicas, Universidade Fe-
}

deral de Minas Gerais (UFMG), Av. Presidente Antônio Carlos 6621, Campus Pampulha, Belo Horizonte, MG 31270-901, Brasil. E-mail: nogueira@ icb.ufmg.br

${ }^{4}$ Laboratório de Doenças das Aves, Escola de Veterinária (EV), UFMG, Av. Presidente Antônio Carlos 6627, Campus Pampulha, Belo Horizonte, MG 31270-901. E-mail: brunoantunes.soares@yahoo.com.br 
RESUMO.- Foram utilizadas as gônadas e vias espermáticas de cinco animais machos, adultos em fase reprodutiva, da espécie Metachirus nudicaudatus Geoffroy 1803, única espécie do gênero, para descrever a morfologia do escroto, do testículo e das vias espermáticas. 0 Metachirus possui escroto pré-peniano e que contém os testículos permanentemente. A pele escrotal é não pigmentada e com poucos pelos e glândulas. A lâmina parietal da túnica vaginal apresenta-se pouco pigmentada. Os testículos são ovais e ligados ao epidídimo através do pedículo testículo-epididimário. Eles são envolvidos, externamente, pela cápsula testicular e sustentados por um estroma de natureza conjuntiva. As células intersticiais são os elementos predominantes no abundante tecido intertubular. Os túbulos seminíferos são largos, enovelados e envolvidos por uma túnica própria fibroelástica, contendo células mióides. 0 epitélio seminífero é formado pelas células espermatogênicas e de Sertoli intercaladas. Os túbulos seminíferos convergem em direção à extremidade capitata do testículo, ficando revestidos por apenas células de sustentação, caracterizando uma região de transição entre túbulos seminíferos e túbulos retos, ocupada por uma estrutura tipo "válvula" que obstrui parcialmente o lume tubular. Os túbulos retos reúnem-se para formar um único dúctulo eferente, que percorre uma pequena extensão intratesticular, atravessa a albugínea e penetra no pedículo testículo-epididimário. A parte flexuosa do dúctulo eferente forma um lóbulo separado na parte medial do corpo do epidídimo. 0 epidídimo é envolvido pela cápsula epididimária e constituído pelo ducto epididimário, que se encontra bastante enovelado. 0 ducto epididimário é revestido por epitélio simples colunar pseudoestratificado apresentando células principais, basais, apicais e de "halo claro". As células principais são predominantes e apresentam características morfológicas e histoquímicas que diferem ao longo do ducto, possibilitando a caracterização de nove diferentes zonas epididimárias. É no lume da zona sete (início da cauda) que começa o pareamento de espermatozoides. Esse fenômeno coincide com alterações morfológicas bem evidentes e uma maior quantidade de mucossubstâncias neutras é secretada nessa zona.0 ducto deferente apresenta-se dividido em três partes: justa-epididimária, funicular e abdominal, baseando nas variações histológicas e histoquímicas de seu epitélio e componentes envolventes. 0 ducto deferente não apresenta ampola e nem cruza o ureter antes de desembocar na uretra. 0 funículo espermático contém o ducto deferente, artéria e veias testiculares, vasos linfáticos, nervos e um desenvolvido músculo cremáster. Seus componentes apresentam modificações estruturais nas regiões proximal, média e distal, sendo notável a peculiar rede admirável.

TERMOS DE INDEXAÇÃO: Escroto, testículo, vias espermáticas, Metachirus nudicaudatus, Didelphidae, Marsupialia, Jupati, epidídimo, histologia, sistema genital masculino.

\section{INTRODUÇÃO}

As três subclasses de mamíferos vivos distinguem-se pelos mecanismos de reprodução que desenvolveram, independentemente, durante 100 milhões de anos. Trabalhos sobre a reprodução de monotremos (Prototheria), marsupiais (Metatheria) e placentários (Eutheria) ajudam a lançar as bases para o estudo da reprodução dos mamíferos, especialmente do surgimento da viviparidade (Tyndale-Biscoe \& Renfree 1987). 0 investimento pré-natal dos monotremos é no ovo. Já os eutérios, considerados mais evoluídos, desenvolveram a placenta, importante órgão através do qual os embriões e fetos retiram e excretam as substâncias necessárias ao seu desenvolvimento. Os mamíferos metatérios (marsupiais) caracterizam-se por apresentarem um curto período de desenvolvimento intra-uterino. Após, os filhotes nascem e dirigem-se para as glândulas mamárias, situadas ou não no marsúpio. Esse grupo tem, portanto, na lactação o principal meio de nutrir os seus filhotes, que nascem com características ontogenéticas pouco desenvolvidas. Os marsupiais, embora não sendo ancestrais diretos dos mamíferos eutérios, representam uma linha evolutiva derivada da sub-classe THERIA (Romer 1985). Estes marsupiais situam-se entre os monotremos e os mamíferos placentários, estando mais próximos dos mamíferos placentários do que dos monotremos (Hunsaker 1977).

Os marsupiais, devido às peculiaridades do seu modo de reprodução e a outros aspectos biológicos, tais como temperatura corporal e tamanho do cérebro, foram considerados, por muito tempo, primitivos em relação aos mamíferos placentários. Tal concepção é atualmente questionada. As características particulares dos marsupiais começam a ser consideradas como adaptações alternativas, sendo provável que marsupiais e placentários tenham tido um ancestral comum (Sharman 1970, Kirsch 1979, Martinelli 1990).

Uma nova percepção vem surgindo nos meios científicos demonstrando que os marsupiais formam um novo e extraordinário modelo para pesquisas biomédicas, podendo complementar os estudos feitos com as espécies convencionais de laboratório e animais domésticos.O estudo da biologia reprodutiva dos marsupiais implica no conhecimento de parâmetros morfológicos tanto do sistema genital feminino como do masculino. Sobre o sistema genital masculino de marsupiais, um dos primeiros estudos foi realizado no gambá por Cowper (1704), que o comparou com o sistema genital feminino, já conhecido e descreveu as diferenças anatômicas encontradas.

0 gênero Metachirus possui uma única espécie, o Jupati, Metachirus nudicaudatus (Geoffroy, 1803). Trata-se de um marsupial da família Didelphidae de hábitos noturnos, terrestre e com ampla distribuição na América do Sul, sendo encontrado em quase todo o Brasil, em locais de florestas densas e campos arbustivos. Seu corpo atinge em média $26,5 \mathrm{~cm}$ de comprimento, sendo coberto de pelos escuros e marrons na região dorsal. Sua cauda mede cerca de $30,0 \mathrm{~cm}$ e tem pelos somente na base. A face é escura e possui duas manchas claras nas regiões supraorbitais. Visando a contribuir para os estudos da biologia da reprodução de marsupiais brasileiros, no presente trabalho encontra-se uma descrição da morfologia do escroto, do testículo e das vias espermáticas de $M$. nudicaudatus.

\section{MATERIAL E MÉTODOS}

Foram utilizados o escroto, o testículo e as vias espermáticas de cinco animais machos, adultos em fase reprodutiva, da espécie Metachirus nudicaudatus Geoffroy, 1803 (autorização 002/93-DE- 
VIS; 008/95 DEVIS Ibama). Para estudo histológico e histoquímico, fragmentos dos órgãos genitais foram fixados em paraformaldeído 4\% em tampão fosfato e em líquido de Bouin (Lillie \& Fullmer 1976), durante 24 horas. Para as secções de testículos, utilizou-se o fixador de Allen, conforme Nogueira \& Redins (1989) durante 20 horas.

0 material fixado foi desidratado em série crescente de álcool etílico, infiltrado e incluído em resina Technovit 7100 - Kulzer (Hidroxietilmetacrilato). Além disso, alguns fragmentos desse material foram desidratados, diafanizados em xilol, infiltrados e incluídos em parafina segundo a técnica de rotina. Os blocos de resina foram cortados em micrótomo Reichert-Jung (cortes de $5 \mu \mathrm{m}$ ), e os de parafina em micrótomo Spencer (American Optical Company), obtendo-se cortes de $7 \mu \mathrm{m}$ de espessura. Para estudo histológico dos diferentes órgãos, foram utilizadas as colorações Hematoxilina-Eosina (HE), Azul de Toluidina-Borato de Sódio, Hematoxilina-Férrica (para os testículos), coloração para fibras elásticas (Nogueira \& Ribeiro 1980) e impregnação argêntica para fibras reticulares (Gomori 1937).

Para histoquímica de glicogênio e mucossubstâncias foram usados os seguintes métodos: Ácido Periódico-Reativo de Schiff (PAS), segundo McManus (1946), digestão pela amilase salivar, seguida de PAS (Lison1960), Alcian-Blue (AB) pH 2,5 (Mowry 1956), Alcian-Blue (AB) pH 1,0 (Lev \& Spicer 1964), Alcian-Blue (AB) $\mathrm{pH}$ 2,5, seguido de PAS (Mowry 1956,Lison 1960), Ninhidrina-Schiff (Yasuma \& Ichikawa 1953) e bloqueio da reação da Ninhidrina-Schiff pelo ácido nitroso (Lillie 1958). As preparações realizadas no material incluído em resina seguiram as indicações de Chiarini-Garcia (1991).

A micrometria de testículos foi realizada com auxílio de ocular micrométrica Zeiss KPL-W 10X, acoplada à objetiva 16X. As medidas (média \pm d.p.m.) foram feitas em 10 secções transversais de túbulos seminíferos e 10 secções longitudinais de túbulos retos de cada animal.

\section{RESULTADOS}

Metachirus nudicaudatus possui escroto pré-peniano e que contém os testículos permanentemente (Fig.1). A pele escrotal é não pigmentada,fina, pilosa e com delgada camada de queratina. A junção dermo-epidérmica é lisa. A derme é de natureza conjuntiva, apresentando as fibras reticulares com distribuição mais ou menos uniforme nessa camada, e formando uma delicada trama na junção dermo-epidérmica, ao redor dos folículos pilosos, glândulas e vasos. Cortes de folículos pilosos são vistos na região mais superficial da derme, associados ou não às pequenas glândulas sebáceas do tipo acinosa-holócrina (Fig.1). A pele da região do funículo espermático apresenta as mesmas características histológicas da pele escrotal. Entretanto, um maior número de folículos pilosos pode ser visto na camada superficial da derme, associados às glândulas sebáceas. 0 tecido subcutâneo é rico em tecido adiposo unilocular e altamente vascularizado e inervado. Ele funde-se com a espessa camada muscular estriada esquelética do músculo cremáster, que se apresenta apoiada na lâmina parietal da túnica vaginal.

A túnica vaginal envolve o testículo, o pedículo testículo-epididimário, o epidídimo e o funículo espermático. Ela possui duas lâminas: visceral e parietal, entre as quais se situa a cavidade vaginal que contem pequena quantidade de líquido. A lâmina visceral é aderida à albugínea testicular e não possui pigmentação. A lâmina parietal da túnica vaginal é delgada, resistente e pouco pigmentada (Fig.1).
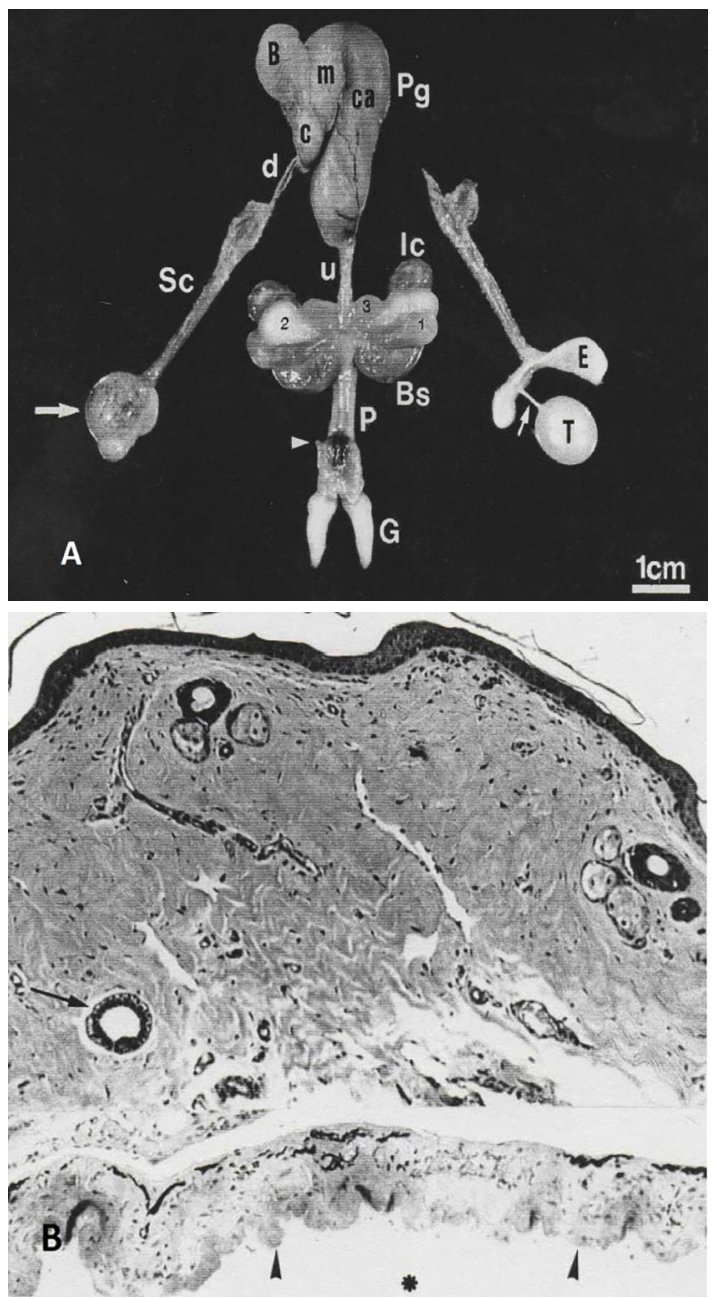

Fig.1. (A) Sistema genital masculino de Metachirus nudicaudatus dissecado e com pênis não distendido. Testículo (T) e epidídimo (E) retirados da túnica vaginal. A seta menor indica o pedículo testículo-epididimário. A seta maior, no lado oposto, mostra os dois órgãos envolvidos pela túnica vaginal. Funículo espermático ( $\mathrm{Sc}$ ), parte abdominal do ducto deferente (d), bexiga (B), próstata (Pg) mostrando seus três segmentos: cranial (c), médio (m), e caudal (ca), uretra membranosa (u), glândulas bulbo-uretrais laterais (1), glândulas bulbo-uretrais intermédias (2), glândulas bulbo-uretrais mediais (3), músculos ísquio-cavernosos (Ic), músculos bulbo-esponjosos (Bs), corpo peniano (P), glande bífida (G). A cabeça da seta mostra a inserção dos músculos retratores do pênis na parte dorsal da flexura sigmóide. (B) Pele escrotal com epiderme fina, sem cunhas epiteliais e sem camada papilar da derme. Folículos pilosos com glândulas sebáceas são observados. A seta mostra uma glândula sudorípara. Na parte profunda vê-se a túnica vaginal contendo melanócitos. As cabeças de seta indicam o mesotélio. 0 asterisco mostra a cavidade vaginal. HE, 76x.

Os testículos são ovais possuem o eixo maior horizontal em relação ao escroto e ligam-se ao epidídimo através do pedículo testículo-epididimário - PTE (Fig.1). 0 PTE é constituído pela parte reta do dúctulo eferente, vasos sanguíneos e linfáticos e nervos, envolvidos por tecido conjuntivo e serosa. Ao se aproximar do epidídimo, esse dúctulo torna-se contorcido e forma uma estrutura bem visualizada, não pigmentada, de forma mais ou menos elíptica, situada ao 
nível do corpo do epidídimo. As formações conjuntivas do testículo compreendem a cápsula testicular e o tecido intertubular. A cápsula testicular apresenta-se muito fibrosa e formada por um tecido fibroelástico. 0 tecido intertubular é formado por tecido conjuntivo, apresentando poucas fibras colágenas sem uma disposição definida. As fibras elásticas são escassas e delicadas, concentrando-se na túnica própria dos túbulos seminíferos e, em maior quantidade, nas túnicas dos vasos. As fibras reticulares são finas e delicadas, formando uma trama ao redor dos túbulos seminíferos e vasos. As células de intersticiais (Leydig) são os elementos predominantes no tecido intertubular. Elas são volumosas e com formato esferoidal. 0 citoplasma é acidófilo e apresenta-se finamente vacuolado. 0 núcleo é esferoidal, vesiculoso e com nucléolos evidentes. Entre as células de Leydig, macrófagos e fibrócitos são frequentemente observados, enquanto mastócitos não foram vistos. Não existe um mediastino definido. 0 parênquima testicular é formado pelas células Leydig e pelos túbulos seminíferos (TS). Os TS são largos (diâmetro de 269,2 $\pm 27,86 \mu \mathrm{m}$ ), longos, enovelados e envolvidos por uma túnica própria. A túnica própria é de natureza fibroelástica, contendo células mióides. 0 epitélio seminífero é formado pelas células de sustentação (Sertoli) e células espermatogênicas intercaladas. As células de sustentação apresentam núcleo esferoidal, grande, vesiculoso e com nucléolo bem corado. Os núcleos podem estar junto à membrana basal ou afastados dela. Os limites dessas células não são bem precisos. As células espermatogênicas (espermatogônias, espermatócitos primários e secundários e espermátides), completam o epitélio seminífero e apresentam características associações celulares nos diferentes estádios do ciclo do epitélio seminífero. As espermatogônias são encontradas junto à membrana basal, podendo ser de dois tipos de acordo com o aspecto e distribuição dos seus grânulos cromatínicos. Os espermatócitos primários são vistos junto ou mesmo afastados da base do epitélio, apresentando diversos tipos morfológicos que variam em função do estádio da prófase meiótica em que se encontram. Já os espermatócitos secundários, esses são vistos entre as figuras de divisão meiótica em menor número, devido à rapidez com que se dividem em espermátides. As espermátides localizam-se normalmente próximas ao lume tubular, exibindo diversos tipos morfológicos: arredondadas, em alongamento e alongadas, de acordo com o grau de diferenciação em espermatozóides. Em secções transversais do túbulo seminífero observam-se somente associações celulares de um único estádio do ciclo do epitélio seminífero (Fig.2).

Os TS convergem em direção à extremidade capitata do testículo e tornam-se mais afilados. Progressivamente, pelo desaparecimento das células espermatogênicas, o túbulo fica revestido pelas células de sustentação, caracterizando a região de transição entre túbulos seminíferos e túbulos retos. Nessa região de transição as células de sustentação (revestimento) tornam-se colunares, grandes, formando uma estrutura tipo "válvula", que obstrui, parcialmente, o lume tubular. A "válvula" ocupa uma pequena extensão do túbulo seminífero $(287,4 \pm 78,20 \mu \mathrm{m}$ de comprimento). Os túbulos retos possuem lume estreito e apresentam-se revestidos por epitélio simples cúbico. Os vários túbulos retos progri-

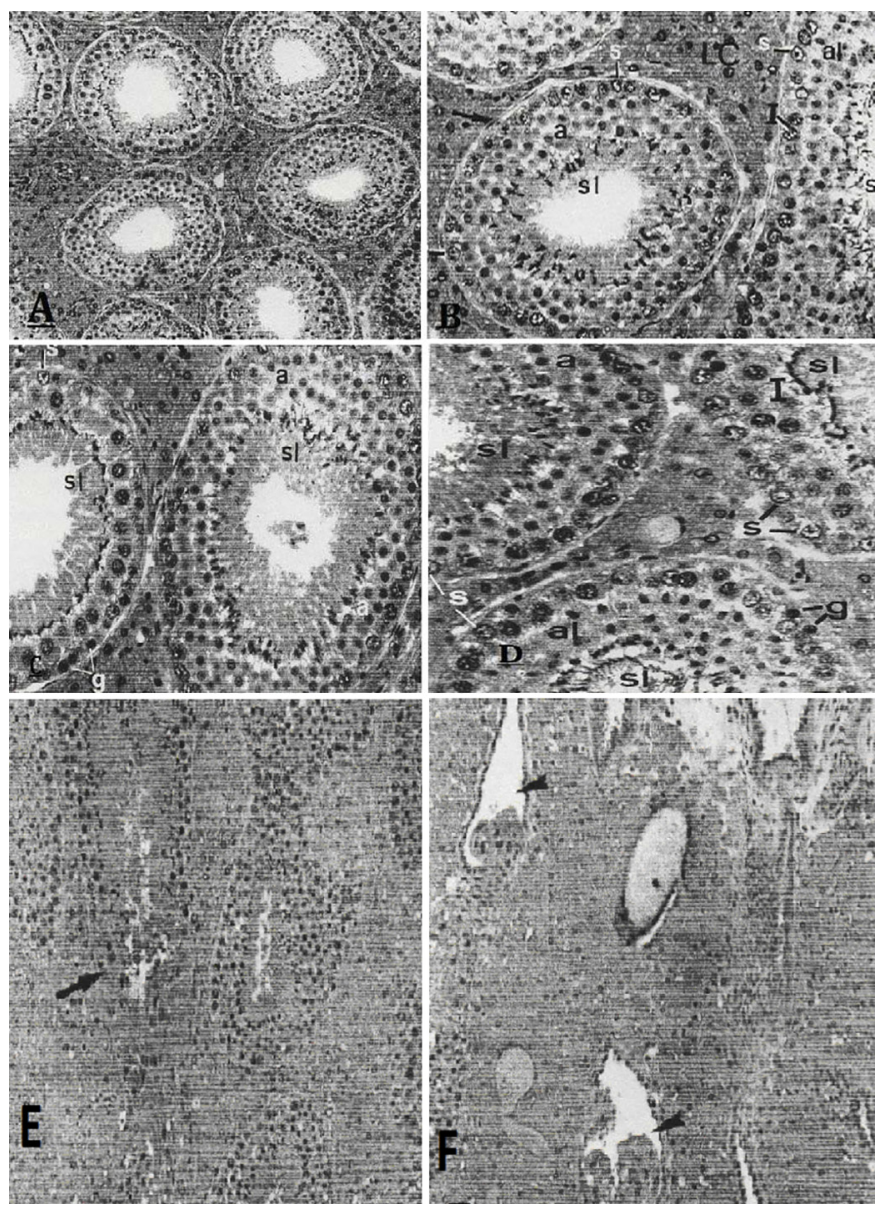

Fig.2. (A) Aspecto panorâmico do testículo. Observar os túbulos seminíferos em diferentes estádios do ciclo do epitélio seminífero e o abundante tecido intertubular. HE, 76x. (B) Tecido intertubular formado predominantemente por células de Leydig (LC) com citoplasma vacuolado. No túbulo seminífero, seccionado transversalmente, observam-se a túnica própria (seta) e as seguintes células: Sertoli (s), espermátide arredondada (a) e espermátide em alongamento (al). No hemi-túbulo, seccionado longitudinalmente, observam-se células de Sertoli (s), espermatócitos I (I), espermátides iniciando o alongamento (al) e espermátides alongadas (sl). HE, 192x. (C) Dois túbulos seminíferos em estádios diferentes onde se observam: espermatogônias (g), células de Sertoli (s), espermatócitos I (I), espermátides alongadas (sl), no túbulo à esquerda; no túbulo à direita observam-se espermátides arredondadas (a) e espermátides alongadas (sl). HE, 192x. (D) Três túbulos seminíferos seccionados transversalmente e em estádios diferentes, onde se observam células de Sertoli (s), espermatogônia (g), espermatócitos I (I), espermátides arredondadas (a), espermátides iniciando o alongamento (al) e espermátides alongadas (sl). HE, 192x. (E) Observar os túbulos seminíferos seccionados em diferentes posições e o abundante tecido intertubular. A seta indica a região de transição de um túbulo seminífero para a estrutura valvular. HE, 192x. (F) Visão panorâmica da região de confluência dos túbulos retos (cabeças de setas) e "válvulas" dos diferentes túbulos. Observar o abundante tecido intertubular nesta região. HE, 192x.

dem em direção a uma região mais ou menos central da extremidade capitata do testículo, para formar um único dúctulo eferente intratesticular. Os túbulos retos desembocam em alturas diferentes ao longo do dúctulo eferente. Poucos 
mastócitos estão restritos a essa área de tecido conjuntivo. Espermatozóides e células descamadas da linhagem espermatogênica são observadas no lume das vias espermáticas intratesticulares. 0 dúctulo eferente intratesticular é revestido por epitélio simples cuboidal. Ele percorre uma pequena extensão testicular $(101,6 \pm 4,21 \mu \mathrm{m}$ de comprimento) e atravessa a albugínea. A albugínea, na região de saída do dúctulo eferente, torna-se mais espessada. Essa região se caracteriza pela entrada da artéria testicular e saída da veia testicular, vasos linfáticos e o dúctulo eferente (Fig.2 e 3).

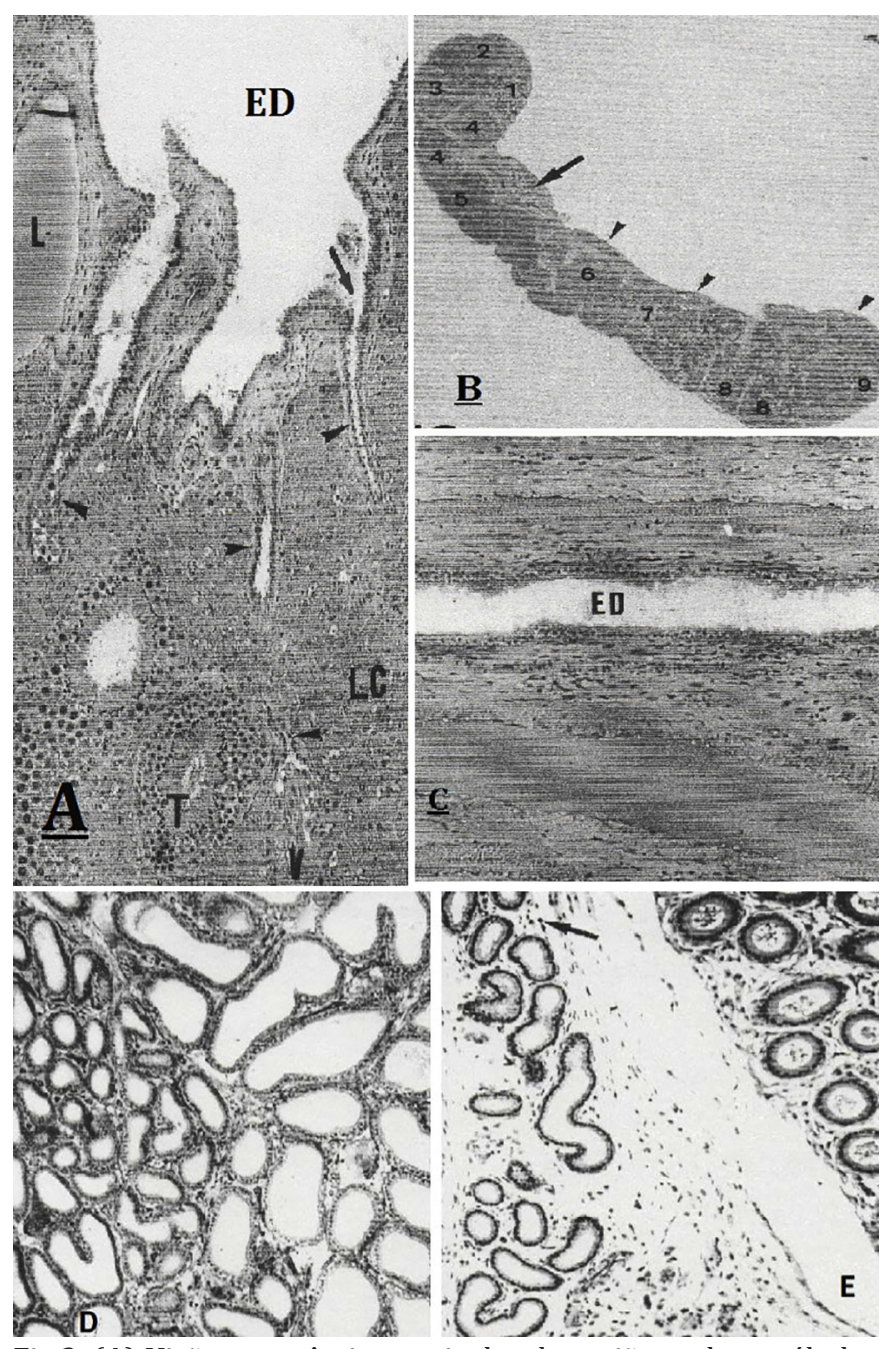

Fig.3. (A) Visão panorâmica testicular da região onde os túbulos retos (cabeça de seta) desembocam para formar um único dúctulo eferente (ED). A seta indica um dos pontos de desembocadura. Túbulo seminífero (T), células de Leydig (LC), "válvula" (V) na transição túbulo seminífero-túbulo reto (cabeça de seta). HE, 192x. (B) Aspecto anatômico do epidídimo e a distribuição de suas 9 zonas; 1 a 3 = cabeça, 4 a 6 = corpo, 7 a 9 = cauda. A seta indica a parte flexuosa do dúctulo eferente e as cabeças de seta mostram o trajeto da parte justa-epididimária do ducto deferente. HE, 4,5x. (C) Secção longitudinal do pedículo testículo-epididimário mostrando a parte reta do dúctulo eferente (ED), vasos e conjuntivo. HE, 76x. (D) Parte flexuosa do dúctulo eferente de lume amplo e irregular à direita e de lume menor e regular à esquerda. HE, 76x. (E) Transição do dúctulo eferente (seta) para formar o ducto epididimário que é visto no canto superior à direita. HE, 76x.
O PTE emerge na extremidade capitata do testículo e dirige-se ao epidídimo. Ele é constituído pela porção extra-testicular do dúctulo eferente, vasos sanguíneos e linfáticos e nervos. Todas estas estruturas estão envolvidas por tecido conjuntivo e, mais externamente, revestidos pelo mesotélio. A parte reta do dúctulo eferente é revestida por epitélio simples colunar, cujas células apresentam núcleos ovóides, vesiculosos e com nucléolo evidente, localizados na base. Estas células estão apoiadas em uma delgada membrana basal PAS positiva. O citoplasma apresenta-se acidófilo, contendo granulações PAS positivas e amilaseresistente. Essas granulações distribuem-se por todo o citoplasma ou nas partes lateral e basal da célula. Em algumas células observa-se uma estrutura grande, esferoidal, também PAS positiva, localizada na base, provavelmente devido ao acúmulo desse material. Expansões apicais celulares são visualizadas e são responsáveis pelo aspecto irregular do lume. Células de halo (linfócitos intraepiteliais) claro podem ser vistas intercaladas na base do epitélio. A secreção contida no lume é PAS positiva, amilase-resistente, mostrando-se na forma amorfa ou granular (Fig.3).

A parte flexuosa do dúctulo eferente forma um lóbulo separado da parte medial do corpo do epidídimo. Ele é envolvido por uma cápsula conjuntiva aderida na sua parte medial à cápsula epididimária. 0 dúctulo eferente, no interior desse lóbulo, é longo, flexuoso e apresenta-se de dois tipos: dúctulo de lume amplo e irregular, ocupando a maior parte do lóbulo e dúctulo de lume menor e com aspecto mais regular, ocupando uma pequena área mais externa do lóbulo. 0 dúctulo de lume amplo apresenta um epitélio simples cuboidal, com núcleo esferoidal e nucléolo evidente. Suas células possuem citoplasma claro e com longas projeções apicais. A superfície apical dessas células apresenta uma convexidade voltada para o lume, conferindo-lhe um aspecto ondulado característico. Granulações citoplasmáticas PAS positivas, amilase-resistentes, localizadas em posição infra e/ou supra-nuclear foram detectadas. 0 conteúdo do lume apresenta reação PAS positiva, amilase-resistente e, frequentemente, espermatozóides não pareados são observados. As células epiteliais são positivas para reação Ninhidrina-Schiff, que se tornou negativa após o bloqueio pelo ácido nitroso. Esse dúctulo se modifica próximo à parte lateral do lóbulo, apresentando lume menor e regular. Ele é revestido por epitélio simples cuboidal com núcleo esférico basal. 0 citoplasma dessas células é basófilo e apresenta maior número de projeções apicais. A medida que esse dúctulo se transiciona para ducto epididimário, ele apresenta apenas granulações citoplasmáticas PAS positivas, amilase-resistentes na região supra-nuclear. Entre as ramificações do dúctulo encontra-se um tecido conjuntivo frouxo bastante vascularizado. Mastócitos são observados entre as células do tecido conjuntivo (Fig.3).

0 epidídimo é revestido pela cápsula epididimária e, mais externamente, pela lâmina visceral da túnica vaginal. A cápsula é constituída por tecido conjuntivo denso, cujas fibras colágenas são espessas e apresentam uma disposição ordenada. As fibras elásticas e reticulares são delicadas, pouco numerosas e predominantemente situadas na parte profunda da cápsula. A cápsula emite septos para o 
interior do órgão, dividindo-o em numerosos lóbulos incompletos (Fig.3). Tanto a cápsula como os septos apresentam-se bastantes vascularizados. 0 estroma intralobular é composto de tecido conjuntivo frouxo, rico em vasos e células. As fibras colágenas são delicadas, abundantes e apresentam uma disposição irregular. Fibras elásticas são delgadas, pouco numerosas e dispõem-se circularmente ao redor do ducto epididimário e na parede de vasos. As fibras reticulares são particularmente abundantes ao redor do ducto, onde formam uma delicada trama. No restante do estroma elas são pouco numerosas e apresentam um arranjo irregular.

O parênquima é constituído pelo ducto epididimário, que se apresenta bastante enovelado e compactamente organizado dentro dos lóbulos. Ele é revestido por epitélio simples colunar pseudo-estratificado, de altura variável, e com projeções apicais. Delgada lâmina própria de tecido conjuntivo dispõe-se circularmente. 0 epitélio epididimário é constituído por três tipos celulares: células principais, basais e apicais. As células principais são colunares, acidófilas, apresentam um núcleo com morfologia e posição variável ao longo do ducto. As células basais situam-se entre as células principais e localizam-se na base do epitélio. Elas apresentam núcleo alongado, vesiculoso, com o eixo maior paralelo a base do epitélio. As células apicais são colunares, acidófilas, núcleo ovoide e vesiculoso situado no terço superior da célula. Linfócitos intra-epiteliais (células de halo claro), com núcleo esférico e denso são vistos ao longo do ducto epididimário. As características morfológicas e histoquímicas das células do epidídimo, bem como o diâmetro e aspecto do lume, com a presença de espermatozoides não pareados e pareados, possibilitaram a caracterização de nove diferentes zonas do epidídimo (Fig.3, 4, 5, 6 e 7).

Ao longo da borda lateral do epidídimo observa-se um ducto de lume amplo, revestido por epitélio colunar. As células epiteliais são estreitas, compactamente organizadas e com citoplasma apical acidófilo. 0 núcleo é ovóide e ocupa os dois terços inferiores da célula. Observa-se, frequentemente, eliminação de glóbulos no ápice das células. Na parte terminal, ao nível da zona VIII epididimária, esse ducto se ramifica, dando origem a túbulos secretores revestidos por epitélio colunar, com núcleo esferoidal e citoplasma claro. As células epiteliais secretam material PAS positivo (Fig.7).

O ducto deferente apresenta-se dividido em três partes: justa-epididimária, funicular e abdominal. Na transição com a cauda do epidídimo, o ducto deferente mostra-se bastante flexuoso, apresentando características morfológicas intermediárias entre ducto epididimário e ducto deferente. 0 lume é amplo, de contorno irregular, podendo ou

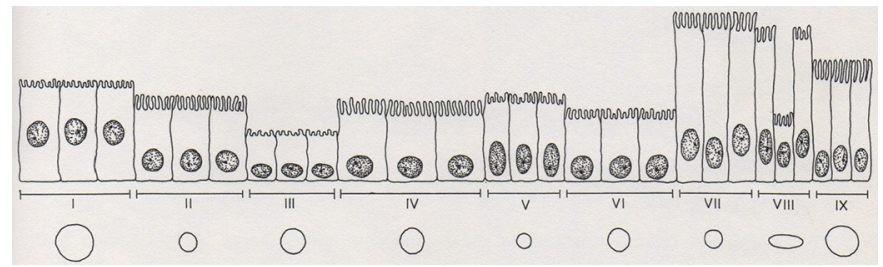

Fig.4. Desenho esquemático dos tipos celulares e do diâmetro encontrados nas nove diferentes zonas do ducto epididimário.

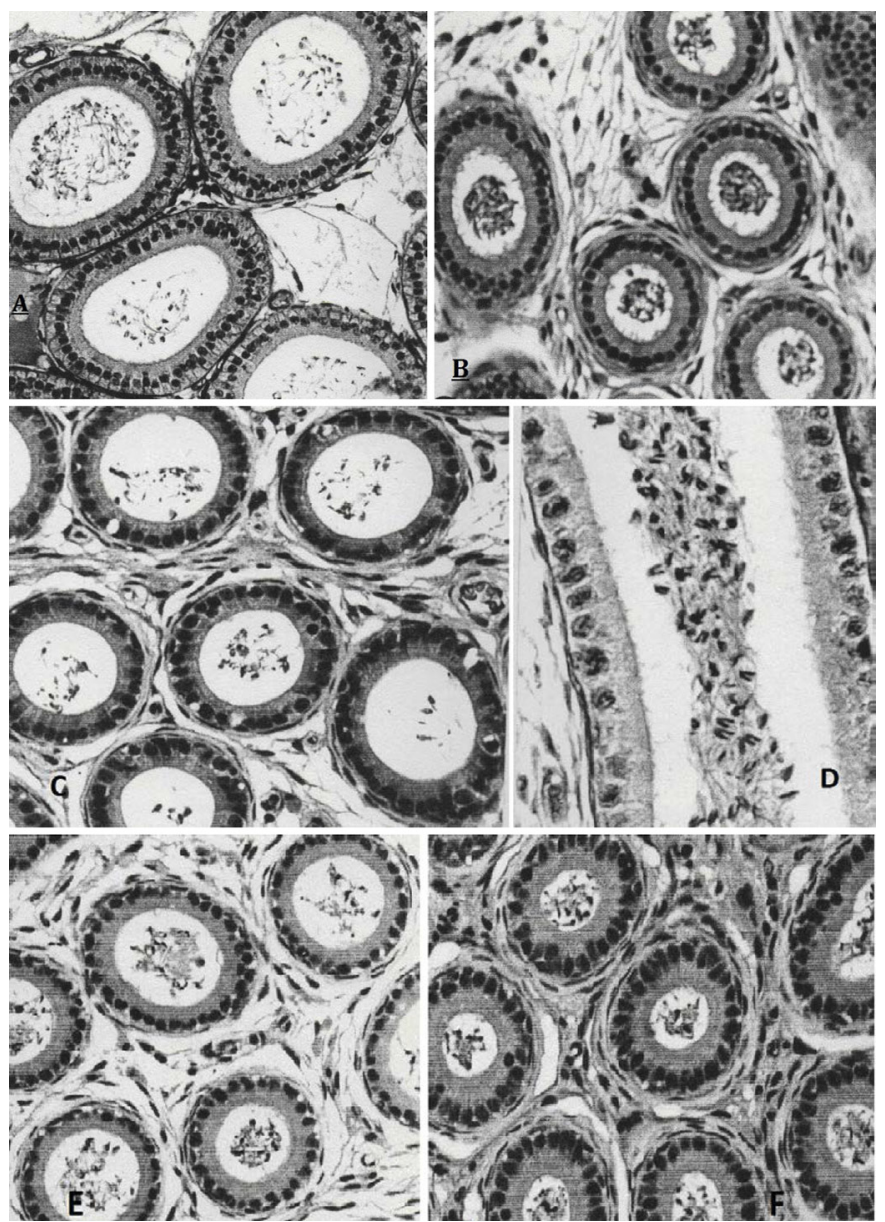

Fig.5. Epidídimo. (A) Zona I; observar a presença de lume bem amplo, circular e de contorno regular, com espermatozóides não pareados em seu interior. HE, 192x. (B) A zona II possui lume menor, circular e de contorno regular, com espermatozóides não pareados em seu interior. As células principais são altas e com numerosas e longas projeções apicais. HE, 192x. (C) A zona III ocupa uma pequena área da cabeça do epidídimo. Ela apresenta o ducto com lume amplo, circular e de contorno regular, contendo também espermatozóides não pareados. As células principais são mais baixas e apresentam poucas projeções apicais. HE, 192x. (D) Espermatozóides não pareados dispersos no lume da zona III. PAS + H, 480x. (E) A zona IV possui lume amplo de contorno circular e regular, porém o epitélio novamente torna-se alto. Espermatozóides não pareados são observados no interior do lume do ducto. HE, 192x. (F) A zona V apresenta lume menor, de contorno regular, contendo espermatozóides não pareados. As células principais são altas e estreitas e com projeções apicais. HE, 192x.

não conter espermatozóides pareados. 0 epitélio de revestimento é simples pseudo-estratificado colunar. As células principais são altas e estreitas com longas projeções apicais. 0 citoplasma é acidófilo, o núcleo é ovóide, vesiculoso e com nucléolo evidente. Algumas células principais apresentam intensa reação PAS positiva, amilase-resistente, principalmente na sua porção supra-nuclear, enquanto outras possuem finas granulações PAS positivas, também amilase-resistentes em todo o seu citoplasma. Grande número de células basais e apicais podem ser vistas intercaladas no epitélio. As células apicais não foram positivas à 

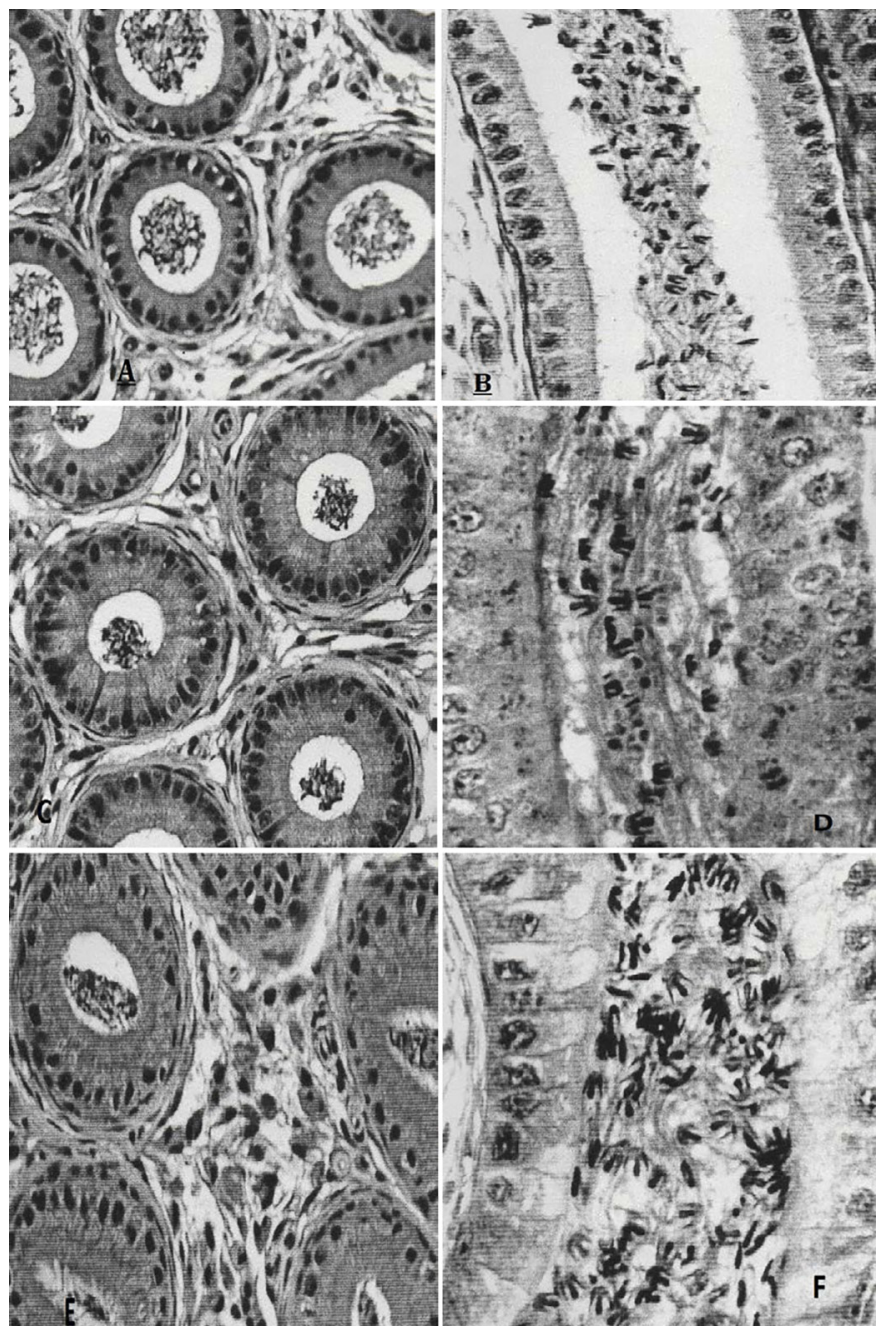

Fig.6. Epidídimo. (A) Na zona VI do ducto epididimário o lume torna-se novamente amplo, contorno circular e regular, contendo espermatozóides não pareados. HE, 192x. (B) Maior concentração de espermatozóides não pareados no lume da zona VI. PAS + H, 480x. (C) A zona VII possui um lume estreito, de contorno regular. É no lume dessa zona que se inicia o pareamento. As células principais são bem altas e com longas projeções apicais. 0 núcleo tem forma alongada e localiza-se em diferentes alturas no terço basal da célula. Algumas dessas células apresentam o núcleo mais denso e seu citoplasma mais acidófilo. HE, 192x. (D) Espermatozóides pareados são observados inicialmente no lume da zona VII. Numerosas granulações PAS positivas são observadas nas regiões supra-nucleares do epitélio ductal. PAS + H, 480x. (E) Na zona VIII, o lume apresenta-se também estreito, porém de forma elíptica, com grande número de espermatozóides pareados no seu interior. HE, 192x. (F) Numerosos espermatozóides pareados no lume da zona VIII. PAS $+\mathrm{H}, 480 \mathrm{x}$.

reação do PAS. Linfócitos intra-epiteliais são vistos com relativa frequência. Pela reação de Ninhidrina-Schiff, as células epiteliais coraram-se moderadamente, e tornaram-se negativas após o bloqueio pelo ácido nitroso. Para $\mathrm{AB} \mathrm{pH}$ 2,5 a reação foi negativa. A lâmina própria do ducto é delgada, com delicadas fibras colágenas e grande quantidade de fibras reticulares formando uma trama ao seu redor. A medida que se afasta dessa região de transição observam-se
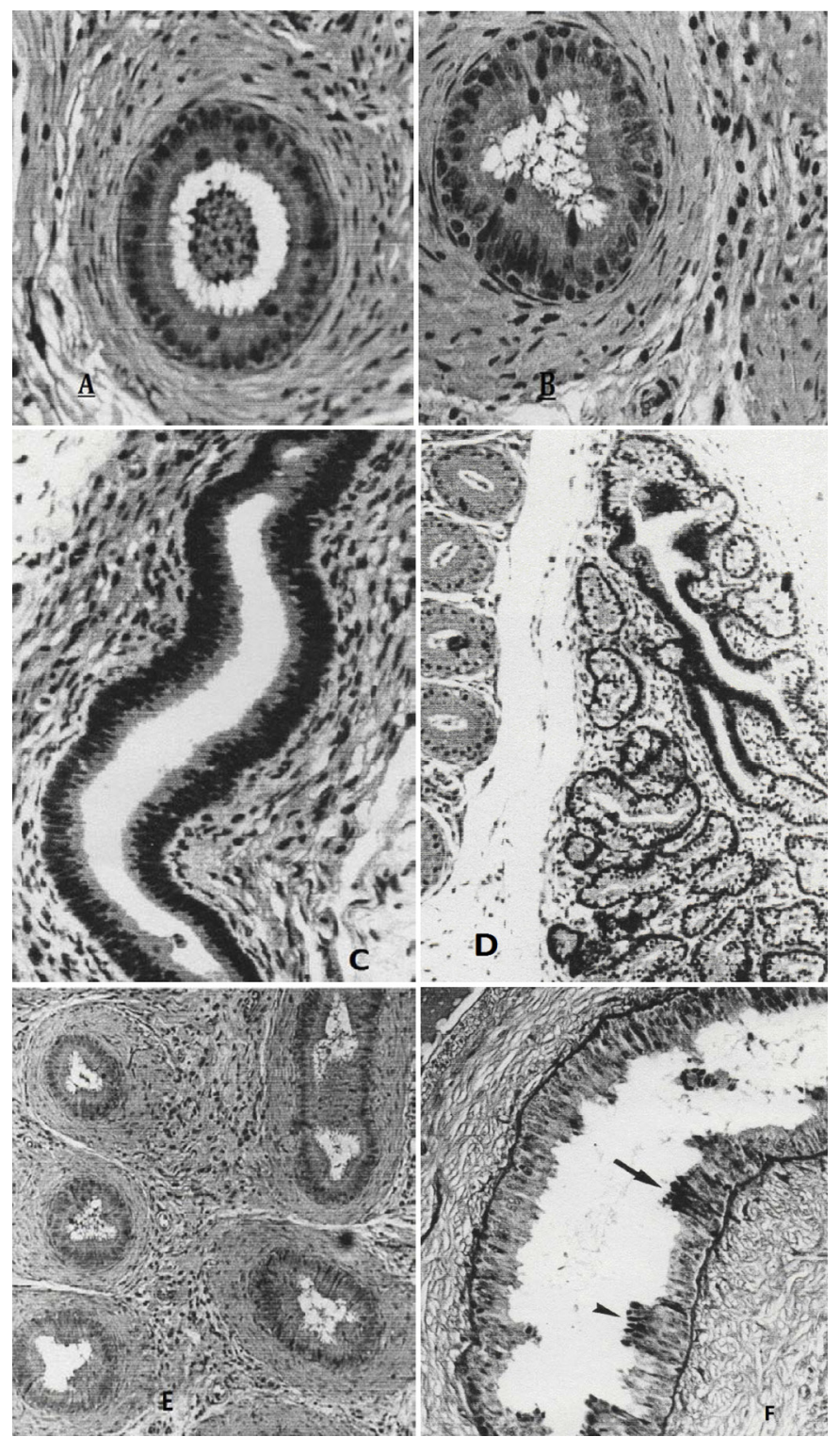

Fig.7. (A) 0 ducto epididimário na zona IX apresenta o lume bem amplo, circular e com grande número de espermatozóides pareados no seu interior. As células principais apresentam-se altas, estreitas, com núcleo ovóide localizado no terço basal em diferentes posições. Essas células possuem longas e numerosas projeções apicais. HE, 192x. (B) Início da transição do ducto epididimário para ducto deferente, onde se observam as modificações na altura do epitélio, no contorno luminal e no espessamento da túnica muscular. HE, 192x. (C) Observar o arranjo epitelial do ducto que percorre a borda lateral do órgão. As células epiteliais são estreitas, compactamente organizadas e com citoplasma apical acidófilo. 0 núcleo é ovóide e ocupa os dois terços inferiores da célula. Observa-se, frequentemente, eliminação de glóbulos no ápice das células. HE, 192x. (D) Ducto lateral com suas ramificações glandulares terminais. Na parte terminal, ao nível da zona VIII epididimária, esse ducto se ramifica, dando origem a túbulos secretores revestidos por epitélio colunar. HE, 76x. (E) Porção inicial flexuosa do ducto deferente, onde se observam os tipos celulares do epitélio e a modificação do contorno luminal. HE, 76x. (F) Detalhe da porção justa-epididimária do ducto deferente. Observar a presença de lume amplo, de contorno mais irregular e PAS positividade do epitélio (seta), bem como da secreção apical (cabeça de seta) sendo eliminada e no lume. PAS, 192x. 


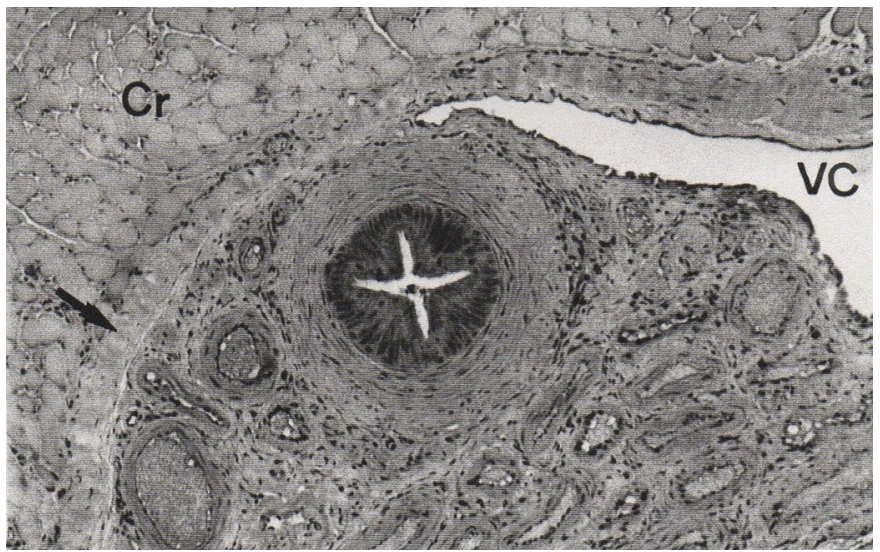

Fig.8. Secção transversal da porção média do funículo espermático. A seta indica a faixa conjuntiva que separa o cremáster (CR) dos demais componentes funiculares (ducto deferente, vasos sanguíneos e linfáticos e nervos); $\mathrm{VC}=$ cavidade vaginal. 0 ducto deferente possui lume estreito, de formato irregular e estrelado. HE, 76x.

algumas fibras elásticas. A camada muscular lisa disposta circularmente é mais desenvolvida que no ducto epididimário. 0 tecido conjuntivo, localizado ao redor do ducto deferente, é muito celular, com delicadas fibras colágenas, poucas e finas fibras elásticas e grande número de fibras reticulares. Mastócitos são vistos no conjuntivo(Fig.7 e 8).

0 ducto deferente na parte justa-epididimária, possui lume amplo, de contorno mais irregular. 0 epitélio de revestimento continua simples pseudo-estratificado colunar, porém com dois tipos de células: altas e baixas, estreitas e com longas projeções apicais. 0 citoplasma permanece acidófilo. 0 núcleo é alongado, vesiculoso, e localizado em diferentes posições. Células apicais, basais e linfócitos intra-epiteliais são frequentemente observados. Histoquimicamente, as células apresentaram forte reação PAS positiva, amilase-resistente, principalmente na parte apical. Pela Ninhidrina-Schiff as células mostraram-se fracamente coradas e tornaram-se negativas após a reação de bloqueio. Alcianofilia pH 2,5 foi negativa. A lâmina própria continua delgada e a camada muscular torna-se mais espessa. 0 tecido conjuntivo que envolve o ducto permanece muito celular e bem vascularizado.Na parte funicular, o ducto deferente possui lume estreito, de formato irregular, "estrelado". 0 epitélio é simples pseudo-estratificado colunar alto. As células apresentam longas e desenvolvidas projeções apicais. As células principais apresentam núcleos alongados, vesiculosos em diferentes posições. Grande número de células basais são vistas, enquanto as apicais são pouco frequentes. Podem-se observar linfócitos intra-epiteliais. Histoquimicamente, as células apresentaram moderada PAS-positividade, amilase-resistente, difusa. Fraca reação positiva para Ninhidrina-Schiff, que se tornou negativa após o bloqueio pelo ácido nitroso. A alcianofilia $\mathrm{pH}$ 2,5 permanece negativa. A lâmina própria apresenta-se pouco desenvolvida e a camada muscular lisa circular mais espessa. 0 tecido conjuntivo que circunda o ducto externamente permanece bastante vascularizado (Fig.7).

O funículo espermático é constituído pelo ducto deferente, artérias e veias testiculares, vasos linfáticos e ner- vos, envolvidos pela musculatura estriada esquelética do músculo cremaster (Fig.8). Esse músculo é separado das demais estruturas por uma faixa de tecido conjuntivo denso. Todas essas estruturas encontram-se envolvidas por tecido conjuntivo e tecido adiposo unilocular. Em quase toda a sua extensão o funículo é envolvido pela pele da haste funicular. Seus componentes apresentam modificações estruturais nas regiões proximal, média e distal do funículo.Na região proximal do funículo, a artéria e a veia testiculares são únicas. As lâminas parietal e visceral delimitam o canal vaginal. Em sua região média observa-se a peculiar ramificação da artéria testicular, que forma uma desenvolvida rede admirável, acompanhada pelas veias homólogas. 0 canal vaginal ainda é parcialmente observado e o músculo cremáster torna-se mais desenvolvido nessa região. Na região distal, os ramos da artéria testicular se reúnem em um só antes de penetrar no testículo. A musculatura esquelética permanece bem desenvolvida e bastante inervada. Poucos adipócitos uniloculares são observados (Fig.8). A parte abdominal do ducto deferente assemelha-se histológica e histoquimicamente à sua parte funicular. Ele apresenta-se envolvido por uma adventícia de tecido conjuntivo, rica em vasos sanguíneos e linfáticos. Externamente, o ducto encontra-se envolvido por uma prega peritonial. Esse ducto desemboca-se na uretra prostática não apresentando dilatação ou ampola.

\section{DISCUSSÃO}

O sistema genital masculino de Metachirus nudicaudatus assemelha-se ao de outros marsupiais americanos e australianos já estudados. Os testículos da maioria são encontrados em um proeminente escroto pré-peniano. As exceções são os marsupiais Notoryctes typhlops, cujos testículos são abdominais e Lasiorhinus latifrons, em que os testículos são escrotais somente durante a estação reprodutiva, retornando à região inguinal no restante do tempo (Setchell 1977).

A pele escrotal de $M$. nudicaudatus é não pigmentada, apresenta poucos pelos na parte média e posterior. A haste funicular é pouco pigmentada, também com poucos pelos. De acordo com Barnes (1977), nos gêneros Marmosa, Caluromys e Antechinus, Nogueira et al. $(1977,2003)$, Nogueira (2012) em Didelphis albiventris e Martinelli (1990) em M. cinerea, a pele escrotal nesses marsupiais apresenta-se pigmentada. Entretanto, não foi observado o escurecimento da pele escrotal em P. opossum (Ribeiro \& Nogueira 1991) e Chironectes minimus (Nogueira et al. 2004). Com relação à presença e a distribuição de pelos no escroto, $M$. nudicaudatus se assemelha ao descrito por Nogueira et al. (1977) em D. albiventris, Ribeiro \& Nogueira (1982) em P. opossum, Martinelli (1990) em M. cinérea e Lima et al. (2013) em G. microtarsus. Em espécies australianas, de acordo com Temple-Smith (1984), a distribuição de pelos no escroto varia entre as espécies e pode mostrar uma correlação com fatores ambientais, tais como temperatura e umidade. Poucas glândulas sudoríparas foram observadas na parte mais profunda da derme, semelhante ao observado em M. cinerea. Em M. nudicaudatus não se encontrou músculo liso no tecido subcutâneo do escroto, ao contrário do observado em D. albiventris (Nogueira et al. 1977)e M. cinérea (Mar- 
tinelli 1990), onde essas fibras estão presentes, análogas à túnica dartos dos mamíferos eutérios.

A túnica vaginal de $M$. nudicaudatus apresenta características histológicas que se assemelham às observadas por Martinelli (1990) em M. cinerea, porém a distribuição de melanócitos na lâmina parietal não se faz em uma camada contínua externa ao músculo cremáster e nem estes estão presentes entre os feixes musculares. Em Metachirus os melanócitos se dispõem em grupos esparsos na parte mais profunda da lâmina parietal. A lâmina visceral não possui pigmentação. A pigmentação da túnica vaginal também é registrada em outros marsupiais americanos e australianos, de acordo com Biggers (1966) em espécies americanas, Ribeiro \& Nogueira (1991) em P. opossum e Costa et al. (1994) em M. nudicaudatus. De acordo com Rodger (1982) em Caenolestes obscurus e Nogueira et al. (2004) em Chironectes minimus, a túnica vaginal nesses marsupiais não apresenta pigmentação. Em espécies australianas, a pigmentação da túnica vaginal também pode ser observada (Setchell 1977, Woolley \& Scarlett 1984, Cummins et al. 1986). O significado funcional dessa pigmentação ainda não está bem definido, mas de acordo com Biggers (1966) em $D$. marsupialis, ela está relacionada com a termorregulação testicular. Novos estudos deverão ser realizados objetivando uma avaliação mais acurada do papel funcional dessa pigmentação na túnica vaginal em marsupiais.

O arranjo estrutural dos testículos de Metachirus nudicaudatus é semelhante ao de outros marsupiais, embora algumas diferenças possam ser observadas. A cápsula testicular é formada pela lâmina visceral da túnica vaginal e pela albugínea (Nogueira et al. 1977, Ribeiro 1981, Nogueira et al. 1999, Barros et al. 2003, Nogueira 2012, Barros 2013, Lima et al. 2013). A existência de uma túnica vasculosa, como descrito por Martinelli (1990) em Marmosa cinerea e Leeson \& Cookson (1974) em mamíferos eutérios, não foi observada em Metachirus. A albugínea testicular de $M$. nudicaudatus apresenta um padrão semelhante ao da $M$. cinerea (Martinelli 1990), Didelphis albiventris (Nogueira et al. 1977, 2003, Nogueira 2012, Barros 2013), Philander opossum (Ribeiro 1981), Santos, et al. (2011) em M. nudicaudatus e por Lima et al. (2013) em G. microtarsus, embora algumas diferenças foram observadas na quantidade e distribuição de fibras colágenas, reticulares e elásticas. Davis et al. (1970) e Leeson \& Cookson (1974) descrevem a presença de fibras musculares lisas na albugínea de mamíferos eutérios. Em Metachirus, como em outros marsupiais já estudados, a exemplo de D. albiventris (Nogueira et al. 1977, Nogueira 2012), P. opossum (Ribeiro 1981) e M. cinerea (Martinelli 1990), não se evidenciou a presença dessas fibras na albugínea do testículo.

O tecido intertubular do testículo de $M$. nudicaudatus é semelhante ao descrito para $D$. albiventris (Nogueira et al. 1977, Barros 2013), P. opossum (Ribeiro 1981), M. cinerea (Martinelli 1990), M. nudicaudatus (Santos et al. 2011) e em G. microtarsus (Lima et al. 2013) . As células de Leydig são os elementos predominantes no tecido intertubular de marsupiais sul americanos (Nogueira \& Redins 1988). Embora fibrócitos e macrófagos também sejam observados nos testículos de Metachirus, os mastócitos não foram observa- dos. Em D. albiventris os macrófagos são numerosos e sua íntima associação com as células de Leydig e sua atividade endocítica sugerem que essas células possam exercer um papel importante na função testicular (Nogueira \& Redins 1988). Em M. nudicaudatus não existe um mediastino testicular definido, como o observado por Martinelli (1990) em M. cinerea e Rodger (1982) em M. murina, P. opossum e $C$. obscurus. Segundo Nogueira et al. (1977) em D. albiventris e Ribeiro (1981) em P. opossum existe um pequeno mediastino testicular constituído de tecido conjuntivo frouxo, com vários tipos celulares.

Os túbulos seminíferos de $M$. nudicaudatus apresentam uma organização estrutural semelhante à descrita para outras espécies de marsupiais (Ribeiro 1981, Martinelli 1990, Nogueira et al. 1999, Santos et al. 2011, Lima et al. 2013). 0 diâmetro dos túbulos de Metachirus (diâmetro de $269,2 \pm 27,86 \mu \mathrm{m}$ ) encontra-se dentro da faixa estabelecida por Woolley (1987) para as famílias Didelphidae e Caenolestidae (241-297 $\mu \mathrm{m})$. De acordo com a descrição de Nogueira et al. (1977) em D. albiventris, Ribeiro (1981) em P. opossum e Martinelli (1990) em M. cinerea, em M. nudicaudatus também se observou a presença de uma túnica própria envolvendo os túbulos seminíferos com os componentes gerais descritos em mamíferos eutérios. Segundo Nogueira et al. (1987), a presença dessa túnica própria contribui para compressão tubular, auxiliando a progressão de espermatozoides não móveis e da secreção tubular dos túbulos seminíferos para as vias intratesticulares. Os componentes celulares do epitélio seminífero de $M$. nudicaudatus são essencialmente os mesmos observados em outros marsupiais (Ribeiro 1981, Martinelli 1990, Queiroz 1991), bem como nos mamíferos eutérios (Setchell 1977, Rodger 1982). As células do epitélio seminífero de M. nudicaudatus apresentam-se organizadas em associações celulares, semelhantes às descritas para D. albiventris (Queiroz \& Nogueira 1992).

Como descrito por Martinelli (1990) em M. cinerea, os túbulos seminíferos de $M$. nudicaudatus diminuem de diâmetro e ligam-se à rede testicular via túbulos retos. $\mathrm{Na}$ região de transição as células tornam-se altas e grandes, formando uma estrutura tipo "válvula". Essa estrutura também foi registrada por Rodger (1982) em M. murina, $P$. opossum, D. albiventris, D. marsupialis e $C$. obscurus e por Woolley \& Scarlett (1984) no Tarsipes rostratus (marsupial australiano), pelo visto parecendo ser uma característica comum do testículo de marsupiais. Segundo Martinelli (1990), essa estrutura apresenta uma real função de válvula, no sentido de evitar um refluxo de espermatozoides e da secreção tubular para os túbulos seminíferos.

Os túbulos retos de $M$. nudicaudatus, próximo à rede do testículo, passam a ser revestidos por epitélio simples cúbico, não se observando nenhuma outra modificação ao longo destes, semelhante ao observado em outros marsupiais (Nogueira et al. 1977, Orsi \& Ferreira 1979, Ribeiro 1981, Rodger 1982, Martinelli 1990). Em M. nudicaudatus, os vários túbulos retos progridem em direção a uma região mais ou menos central da extremidade capitata, para formar um único dúctulo eferente intratesticular. Como acontece em vários marsupiais americanos, as desembocaduras 
dos túbulos retos ocorrem em várias alturas ao longo desse dúctulo, ao contrário do que se observa em M. impavida (Woolley 1987) e em M. cinerea (Martinelli 1990), onde os túbulos fundem-se em um só nível para formar o único dúctulo eferente.Semelhante ao que acontece em outros Didelphideos (Rodger 1982, Woolley 1987, Martinelli 1990), exceto C. obscurus (Rodger 1982), o dúctulo eferente do $M$. nudicaudatus acompanha os principais vasos sanguíneos testiculares.

Em $M$. nudicaudatus, a rede testicular não é típica e ocupa uma região mais ou menos central da extremidade capitata. Setchell (1977) registrou uma rede testicular em marsupiais, que se desenvolve ao nascimento, entre veias e artérias. Orsi \& Ferreira (1979) discutiram a presença da rede em $D$. albiventris. Ribeiro (1981) não observou uma rede testicular típica emP. opossum, bem como Nogueira et al. (1977) em D. albiventris, Martinelli (1990) em M. cinerea e Woolley (1987) em alguns marsupiais australianos. Uma faixa de tecido conjuntivo, contendo mastócitos, é observada nessa região ao redor dos túbulos retos e do dúctulo eferente. Essa descrição se assemelha ao observado em alguns marsupiais americanos e australianos, incluindo espécies descritas por Rodger (1982) e Woolley (1987). Fica claro que a variedade de formas da rede testicular observada em mamíferos eutérios não ocorre nos marsupiais sul americanos.

O pedículo testículo-epididimário de $M$. nudicaudatus apresenta os componentes estruturais descritos por Ladman (1967) em D. virginiana, Nogueira et al. (1977) e Nogueira (2012) em D. albiventris, Ribeiro (1981) em $P$. opossume Martinelli (1990) em M. cinérea. Semelhante ao observado por Martinelli (1990) em M. cinerea, M. nudicaudatus também não apresenta uma separação de vasos e dúctulo eferente em lobos distintos, ao contrário do observado por Rodger (1982) em D. albiventris. M. nudicaudatus apresenta um único dúctulo eferente, constituído por uma parte extratesticular reta, que se ramifica próximo ao epidídimo, constituindo a parte flexuosa do dúctulo eferente. A primeira descrição de um único dúctulo eferente em marsupial foi feita por Cowper (1704). Segundo Chase (1939), os marsupiais diferem dos mamíferos eutérios por apresentarem somente um dúctulo eferente ligando testículo ao epidídimo. Um único dúctulo eferente também foi descrito por Nogueira et al. (1977), Ribeiro (1981), Rodger (1982), Tyndale-Biscoe \& Renfree (1987), Woolley (1987) e Martinelli (1990) em marsupiais americanos e Woolley \& Scarlet (1984), Tyndale-Biscoe \& Renfree (1987) em marsupiais australianos. Embora alguns autores afirmem terem observado mais de um dúctulo unindo os dois órgãos em marsupiais americanos (Ladman 1967, Dawson et al. 1988) e em marsupiais australianos (Tyndale-Biscoe \& Refree 1987), essa observação parece ser improvável, uma vez que, como acontece em outros marsupiais (Nogueira et al. 1977, Ribeiro 1981, Rodger 1982, Woolley 1987, Martinelli 1990), esse dúctulo se ramifica próximo ao epidídimo, originando dúctulos de calibres menores que irão constituir a parte flexuosa do dúctulo eferente.

0 revestimento epitelial da parte reta do dúctulo eferente de M. nudicaudatus assemelha-se ao registrado por Mar- tinelli (1990) em M. cinerea. Em Metachirus, a parte flexuosa do dúctulo forma um lóbulo distinto não pigmentado, na parte medial do corpo epididimário, envolvido por uma cápsula conjuntiva aderida à capsula do epidídimo. Essa estrutura lobular também foi descrita em várias espécies de marsupiais americanos, inclusive apresentando pigmentação (Martan et al. 1967 nos gêneros Marmosa e Philander e nas espécies $D$. virginiana e Caluromys derbianus, Nogueira et al. 1977 em D. albiventrise Martinelli 1990 em M. cinerea). Segundo Rodger (1982), semelhante ao observado em $M$. nudicaudatus, essa estrutura não apresentou pigmentação nas espécies M. murina, P. opossum, D. marsupialis, $D$. albiventris e Caenolestes obscurus. A presença de uma parte flexuosa distinta não tem sido descrita em espécies australianas; todavia em Trichosurus vulpecula, segundo Woolley \& Scarlett (1984), o dúctulo eferente torna-se enovelado ao entrar na cabeça do epidídimo. Semelhante ao descrito em D. albiventris por Nogueira et al. (1977), em P. opossum por Ribeiro (1981) e em M. cinerea por Martinelli (1990), não são observadas células ciliadas no epitélio do dúctulo eferente de $M$. nudicaudatus, embora a presença de células ciliadas e não ciliadas no epitélio ductular seja descrita em vários marsupiais americanos e australianos. Segundo a descrição de Ladman (1967), as células não ciliadas da parte reta do dúctulo eferente possuem microvilosidades e canalículos apicais contendo material filamentoso associado à membrana, sugerindo uma função absortiva. Rodger (1982) observou que, emP. opossum e M. murina, as células não ciliadas eram mais altas que as ciliadas, dando ao epitélio uma aparência irregular. Como relata Martinelli (1990), é possível que a não observação dos cílios no epitélio nas partes reta e flexuosa do dúctulo eferente desses didelphideos seja devida à metodologia utilizada para estudos histológicos, que não preservou essas estruturas celulares. Todavia, um estudo ao microscópico eletrônico de transmissão certamente trará contribuições para o melhor conhecimento morfofuncional dessa peculiar estrutura dos marsupiais.

Com relação às reações histoquímicas realizadas no epitélio do dúctulo eferente de $M$. nudicaudatus, suas células contém mucossubstâncias neutras. De acordo com o observado por outros autores, em espécies diferentes, existe uma significativa diferença quanto à natureza dos grânulos presentes nas células do dúctulo (Nogueira et al. 1977 em D. albiventris, Ribeiro 1981 em P. opossum, Martan et al. 1967 em Marmosa sp. e C. derbianus e Martinelli 1990 em M. cinerea). A pequena quantidade de espermatozóides observada no interior da parte flexuosa do dúctulo eferente sugere um trânsito rápido através desta estrutura.

O epidídimo é revestido pela cápsula epididimária e, mais externamente, pela lâmina visceral da túnica vaginal. A cápsula é constituída por tecido conjuntivo denso e assemelha-se estruturalmente à descrita em $M$. cinerea por Martinelli (1990), não se observando também a presença de fibras musculares lisas. $O$ estroma intralobular de $M$. nudicaudatus também apresenta os mesmos constituintes básicos descritos em P. opossum (Ribeiro 1981), em M. cinerea (Martinelli 1990) e em M. nudicaudatus (Santos et al. 2011). Como nessas espécies, as fibras reticulares são 
particularmente abundantes ao redor do ducto epididimário e parede de vasos, ao contrário do observado por Orsi et al. (1980a) em D. albiventris, onde essas fibras são escassas ao redor do ducto. De acordo com as observações de Anderson et al. (1979) em D. virginiana, Ribeiro (1981) em P. opossum e Martinelli (1990) em M. cinerea, os mastócitos também são numerosos no estroma epididimário de M. nudicaudatus. No epidídimo de M. nudicaudatus, como no de $M$. cinerea, também não se pôde observar a presença de células mio-epiteliais na camada subepitelial, provavelmente devido a não utilização de técnicas específicas para evidenciação das mesmas.

O parênquima é constituído pelo ducto epididimário, que se apresenta bastante enovelado e compactamente organizado dentro dos lóbulos. 0 epitélio de revestimento do ducto epididimário de M. nudicaudatus é semelhante ao observado em M. murina (Rodger 1982), em M. cinerea (Martinelli 1990) e G. microtarsus (Lima et al. 2013). Ele é do tipo simples pseudo-estratificado colunar e constituído por três principais tipos célulares: células principais, basais e apicais, podendo-se também observar, ocasionalmente, linfócitos intra-epiteliais. Ribeiro (1981) observou em $P$. opossum cinco tipos celulares no epitélio epididimário, com predomínio de células colunares principais, semelhante ao descrito por Orsi et al. (1980b) em D. albiventris. Em D. virginiana, células principais, basais e células de "halo" são descritas no epitélio epididimário (Kelce et al. 1987). Segundo Jones et al. (1984), o epitélio epididimário de Macropus eugenii, é constituído por cinco tipos celulares: células principais, basais, apicais, células ricas em mitocôndrias e linfócitos intra-epiteliais. EmTarsipes rostratus, Cummins et al. (1986) observaram que as células principais e basais eram os tipos predominantes no epitélio do epidídimo. Outros tipos celulares, porém de menor ocorrência, também foram observados, tais como células ricas em lipídios, células fagocíticas, células claras e células de "halo". Segundo esses autores, as células ricas em lipídios são muito semelhantes às células principais, exceto pela presença de grandes massas lipídicas. Células principais fagocíticas também são observadas em Trichosurus vulpecula (Temple-Smith 1984), que sugere ser essa célula uma forma especializada da célula principal, capaz de remover seletivamente gotículas citoplasmáticas do lume. As células claras parecem ser semelhantes às observadas no epidídimo do rato (Brown \& Montesano 1981). A função desse tipo celular é desconhecida. Com relação às células de "halo", essas também podem ser observadas no epidídimo de mamíferos eutérios, sendo provavelmente linfócitos migratórios (Hoffer et al. 1973, Dym \& Romrel 1975). Taggart \& Temple-Smith (1989) observaram no epitélio do epidídimo de Antechinus stuartii que células principais e basais eram frequentes, enquanto células claras e células ricas em mitocôndrias eram escassas. Quatro tipos celulares: células principais, basais, células ricas em mitocôndrias e células elétron-lúcidas foram identificadas no epitélio epididimário de Phascolarcto scinereus (Temple-Smith \& Taggart 1990). Segundo esses autores, nenhuma região especializada de células principais fagocíticas foi observada.

0 ducto epididimário de $M$. nudicaudatus pode ser di- vidido em nove zonas histológicas, baseadas no aspecto das células principais e do lume do ducto. Ribeiro (1981) descreve diferenças morfológicas do epitélio ao longo do ducto epididimário e P. opossum, mas sem dividi-lo em zonas histológicas. Em D. albiventris (Orsi et al. 1981) e em $M$. cinerea (Martinelli 1990,1992) puderam-se observar sete zonas epididimárias, baseadas nas características do epitélio, porém existem diferenças entre as duas espécies. Em $D$. virginiana, Kelce et al. (1987) observaram três regiões histológicas epididimárias (segmentos proximal, médio e distal). Rodger (1982) também dividiu o epidídimo em zonas histológicas (três a cinco) nas espécies por ele examinadas, observando uma variação entre as espécies. Cummins et al. (1986) descrevem três principais zonas funcionais (segmentos inicial, médio e terminal) no epidídimo de Tarsipes rostratus, baseadas no tipo epitelial e em evidências ultra-estruturais da maturação espermática. A divisão do epidídimo também foi feita em outros marsupiais australianos (Jones et al. 1984, Temple-Smith 1984a), bem como também foi feita em mamíferos eutérios (Amann 1987, Viotto et al. 1988), entre outros. O epidídimo de marsupiais, semelhante ao dos mamíferos eutérios, pode ser dividido, morfologicamente, em três partes principais, as quais refletem amplamente diferenças funcionais: absorção de fluido (cabeça do epidídimo), maturação espermática (corpo do epidídimo) e armazenamento de espermatozóides (cauda do epidídimo) conforme Setchell (1977), Amann \& Shanbacher (1983), Cummins et al. (1986), Temple-Smith (1984) e Tyndale-Biscoe \& Renfree (1987).

0 epidídimo de $M$. nudicaudatus na zona I possui lume bem amplo, as suas células epiteliais são altas e com projeções apicais. Segundo Martinelli $(1990,1992)$, essas projeções são provavelmente microvilosidades. Conforme as técnicas histoquímicas utilizadas, as células principais nessa região contêm mucossubstâncias neutras. Esse material pode representar produtos de reabsorção ou até mesmo secreção celular, segundo Amann (1987) em mamíferos eutérios e Martinelli $(1990,1992)$ em M. cinerea. Segundo alguns autores, Jones et al. (1984) no Macropus eugenii, Cummins et al. (1986) em Tarsipes rostratus e Kelce et al. (1987) em Didelphis virginiana, as células do segmento inicial do epidídimo apresentam características ultra-estruturais que sugerem estarem envolvidas na reabsorção de fluido, causando um aumento na concentração de espermatozóides ao longo do ducto. A zona epididimária II apresenta lume menor e epitélio mais baixo. As células principais produzem mucossubstâncias neutras e apresentam as mais numerosas e maiores projeções apicais da cabeça. Essas características morfológicas sugerem que essa zona seja o local de maior reabsorção de fluido da cabeça do epidídimo.A zona III do epidídimo ocupa pequena área da cabeça epididimária. 0 lume do ducto é amplo, circular e de contorno regular. 0 epitélio apresenta-se baixo, as células mostram poucas projeções apicais e contêm também mucossubstâncias neutras. Essas modificações morfológicas indicam uma diminuição da atividade absortiva nessa zona da cabeça, fato também sugerido por Amann (1987) em mamíferos eutérios. Em todas as três zonas da cabeça do epidídimo espermatozóides não pareados foram obser- 
vados no lume.As zonas epididimárias IV, V e VI ocupam toda a extensão do corpo epididimário. As células nessas regiões apresentam longas e desenvolvidas projeções apicais. Histoquimicamente, elas contêm mucossubstâncias neutras e as reações são mais acentuadas nas projeções apicais. Espermatozóides não pareados também são vistos no lume dessas zonas. As zonas do corpo epididimário apresentam aspectos morfológicos distintos, mas têm um padrão de organização semelhante ao da cabeça. Esses dados sugerem em parte funções análogas às da cabeça do epidídimo, embora classicamente o corpo do epidídimo esteja relacionado com a maturação dos espermatozóides. É no lume da zona VII epididimária (início da cauda) de $M$. nudicaudatus que se observa o pareamento de espermatozóides. As alterações morfológicas e as reações histoquímicas são bem acentuadas nessa zona. 0 lume é estreito, o epitélio apresenta-se alto, as células principais são altas e com projeções apicais. Uma maior quantidade de mucossubstâncias neutras, tanto no citoplasma como na borda apical das células, pode ser observada. 0 lume também apresenta glóbulos de mucossubstâncias neutras.

Martinelli (1990, 1992), em $M$. cinerea, observou os primeiros espermatozóides pareados na zona $V$ epididimária. Foi detectada nessa zona presença de sialomucinas nas desenvolvidas projeções apicais e maior quantidade de mucossubstâncias neutras no citoplasma das células principais, sugerindo um aumento dos processos de síntese e/ ou absorção nas células principais. Essas modificações possivelmente estão relacionadas com as modificações dos espermatozóides em trânsito no epidídimo, ou melhor, com a maturação espermática.

Kelce et al. (1987) em D. virginiana sugeriram que tanto a síntese de secreção protéica como o nível da atividade de 5 - $\alpha$-redutase epididimária estão relacionados com mudanças morfológicas no espermatozóide durante a sua passagem pelo epidídimo, inclusive o pareamento, uma vez que esse processo é andrógeno-dependente. Esses autores salientam que o fenômeno de pareamento possivelmente está relacionado com a maturação espermática. Rodger (1982) observou que o pareamento de espermatozóides estava associado com alterações no aspecto do túbulo e do epitélio de revestimento da região onde ocorria o fenômeno, nas espécies por ele estudadas (D. marsupialis, D. albiventris, $P$. opossum e Caenolestes obscurus). Esse relato também pode ser considerado para o Metachirus e $M$. cinerea (Martinelli 1990, 1992), uma vez que essas alterações também foram registradas nessas espécies.

O significado funcional do pareamento de espermatozóides ainda não está claro. Esse fenômeno provavelmente ocorre em todos marsupiais americanos (Biggers \& Creed 1962, Biggers et al. 1964, Biggers 1966), exceto no Dromiciops australis (Temple-Smith 1987), mas não é observado em espécies australianas (Biggers et al. 1964, Harding et al. 1979, Barbour 1977, Temple-Smith 1984,1987, Taggart et al. 1993).0 processo de maturação espermática nos marsupiais é mais evidente e complexo que nos outros grupos de mamíferos. Durante a passagem dos espermatozóides pelo epidídimo, eles apresentam modificações estruturais da maturação espermática (Temple-Smith \& Bedfort 1976,
Cummins et al. 1986, Temple-Smith1984, Lin \& Rodger 1999). A presença de células fagocíticas no epitélio epididimário e de gotículas citoplasmáticas no lume destacadas dos espermatozóides, parece também estar relacionada com o fenômeno da maturação espermática (Temple-Smith 1984b, em Trichosurus vulpecula).

Na zona epididimária VIII, são observadas alterações morfológicas do epitélio, como a presença de células altas e baixas intercaladas, dando ao lume um aspecto elíptico peculiar. As projeções apicais celulares são longas e delgadas. Mucossubstâncias neutras continuam presentes e bastante acentuada na borda apical das células epiteliais. A zona IX epididimária de $M$. nudicaudatus apresenta lume bem amplo, o contorno volta a ser circular, contendo grande número de espermatozóides pareados no seu interior. As células principais são altas e apresentam longas e numerosas projeções apicais. Na região supra-nuclear pode-se observar a presença de mucossubstâncias neutras. Essas características morfológicas e histoquímicas sugerem que a cauda do epidídimo também está relacionada com processos de secreção e absorção, além da sua principal função que é de armazenamento de espermatozóides. Em D. albiventris (Orsi 1982) e em M. cinerea (Martinelli 1990, 1992), também foram observadas características morfológicas e histoquímicas que se relacionam com processos secretórios e absortivos na cauda epididimária.

Em $M$. nudicaudatus foi observado a presença de um ducto ao longo da borda lateral do epidídimo. Esse ducto se ramifica na sua porção terminal dando origem a túbulos secretores. Essa estrutura também foi observada por Martinelli $(1990,1992)$ em marsupiais americanos por eles estudados. De acordo com alguns autores (Patten 1948, Noden \& De Lahunta 1985) essa estrutura seria um remanescente embrionário do ducto paramesonéfrico.

$\mathrm{O}$ ducto deferente de $M$. nudicaudatus foi dividido em três partes: justa-epididimária, funicular e abdominal, baseado nas variações histológicas e histoquímicas de seu epitélio e na camada muscular. Essas observações se assemelham às relatadas por Ribeiro (1981) em P. opossum, Martinelli (1990) em M. cinérea, Santos et al. (2011) em M. nudicaudatus e por Lima et al. (2013) em G. Microtarsus. Na parte justa-epididimária, o ducto deferente de $M$. nudicaudatus apresenta características morfológicas que se assemelham às de $P$. opossum (Ribeiro 1981) e $M$. cinerea (Martinelli 1990). Na parte funicular, o ducto possui lume estreito, com formato "estrelado". Seu epitélio de revestimento torna-se mais alto e as projeções apicais bem mais desenvolvidas. Tanto a lâmina própria como a camada muscular lisa tornam-se mais espessas que na parte anterior. Essas observações são similares às registradas por Ribeiro (1981) em $P$. opossum, porém diferem na presença de áreas de estratificação do epitélio nessa última espécie. Em M. cinerea (Martinelli 1990), o epitélio do ducto deferente nessa parte apresenta-se mais baixo que o da parte anterior e o contorno do mesmo é alongado. Machado et al. (1982) descrevem em $D$. albiventris uma camada muscular delicada, constituída de uma única camada de fibras musculares lisas com disposição circular. Esses autores não observaram diferenças histológicas ao longo do ducto deferente nessa 
espécie. Rodger (1982) em D. marsupialis, D. albiventris, $P$. opossum e M. murina, observou que o ducto deferente consistia de um tubo muscular relativamente simples que ligava o epidídimo à uretra prostática. Contudo, no Caenolestes, ao contrário desses didelphideos e até mesmo de outros marsupiais, o ducto em sua extremidade distal, adjacente à próstata, assumiu uma forma distinta semelhante à "ampola". O epitélio nessa região, ao contrário dos outros didelphideos, parecia ser secretório. Tal estrutura ainda não tinha sido descrita em outros marsupiais, tanto americanos como australianos.

As células epiteliais do ducto deferente de $M$. nudicaudatus contêm mucossubstâncias neutras, em toda a sua extensão do ducto. Em M. cinerea, Martinelli (1990) detectou mucossubstâncias neutras ao longo do ducto e sialomucinas nas partes epididimária e abdominal. Como sugere Martinelli (1990), essas substâncias observadas no epitélio do ducto deferente podem estas relacionadas com produtos de secreção, uma vez que as células também apresentam numerosas projeções apicais ou poderiam ser produtos de reabsorção de líquido testicular e epididimário.

O funículo espermático de M. nudicaudatus apresenta os mesmos componentes estruturais dos outros marsupiais (Nogueira et al. 1977, Setchell 1977, Ribeiro 1981, Machado et al. 1982, Tyndale-Biscoe \& Renfree 1987, Martinelli 1990). Uma das características mais notáveis do funículo espermático de marsupiais é o desenvolvido músculo cremaster, que quase sempre envolve os outros componentes do funículo (Nogueira et al. 1977). Essa desenvolvida musculatura permite que os testículos, quase sempre situados no escroto, sejam aproximados da parede corporal (Setchell 1977, Tyndale-Biscoe \& Renfree 1987). Machado et al. (1982), em D. albiventris, sugerem que essa musculatura participa no mecanismo termorregulador e no transporte de espermatozóides, tanto durante à atividade sexual como na espermatorreia observada nos marsupiais. No funículo espermático deM. nudicaudatus também pode-se observar a presença de uma desenvolvida rede admirável, formada por ramos da artéria testicular e acompanhada por veias testiculares. De acordo com alguns autores, essa é uma característica peculiar de marsupiais (Harrison 1949, Barnett \& Brazenor 1958, Godinho et al. 1977, Setchell 1977, Ribeiro 1981, Temple-Smith 1984a, Martinelli 1990, Nogueira et al. 2004), porém ausente em pequenas espécies, incluindo Notoryctes, pequeno marsupial com testículos abdominais. Alguns autores discutem a presença de vasos linfáticos na rede admirável (Heddle \& Guiller 1970, Barbour 1977, Nogueira et al. 1977, Setchell 1977, Ribeiro 1981, Tyndale-Biscoe \& Renfree 1987, Martinelli 1990). Embora se tenham observado vasos linfáticos ao longo do funículo espermático de $M$. nudicaudatus, bem como em $P$. opossum (Ribeiro 1981), parece que esses vasos não fazem parte dessa rede.

Lee \& O'Shea (1977)descrevem anastomoses artério-venosas na rede admirável do funículo espermático de algumas espécies de marsupiais australianos. Com relação ao significado funcional dessas anastomoses no funículo espermático Godinho \& Setchell (1975) e Wensing \& Dukstra (1981) sugerem que elas participam na transferência de testosterona do plexo pampiniforme para a artéria testicular, mantendo assim altas concentrações desse hormônio nos testículos. As funções da rede admirável no funículo têm sido abordadas por vários autores. Para alguns, a rede não tem função termorreguladora (Heddle \& Guiller 1970); para outros, ela é responsável pela manutenção da temperatura escrotal e testicular abaixo da temperatura corporal (Barnett \& Brazenor 1958, Biggers 1966, Godinho et al. 1977, Setchell 1977, Temple-Smith 1984a, Tyndale-Biscoe \& Renfree 1987). Em alguns marsupiais australianos, Heddle \& Guiller (1970) afirmam que a rede não tem função termorreguladora e que a temperatura testicular é similar à corporal. Outras funções, como bomba para o retorno do sangue dos testículos e eliminação do pulso arterial, também têm sido sugeridas por Heddle \& Guiller (1970), porém essas funções ainda não estão bem esclarecidas.

\section{CONCLUSÕES}

Embora a morfologia do sistema genital masculino do jupati, Metachirus nudicaudatus, assemelhe-se nos aspectos gerais à de outros didelphideos já estudados, algumas particularidades nessa espécie foram observadas.

Os túbulos retos desembocam em alturas diferentes ao longo do único dúctulo eferente; as peculiares características morfo-histoquímicas da parte flexuosa do dúctulo eferente; a divisão do epidídimo em nove diferentes zonas, com o pareamento dos espermatozóides iniciando-se na zona sete (primeira porção da cauda do epidídimo), onde se observa uma maior atividade secretora.

Essas características de Metachirus poderão servir de subsídios para o melhor conhecimento morfológico e funcional do sistema genital masculino e compreensão da biologia reprodutiva de marsupiais americanos da família Didelphidae.

Com isso, contribuindo, sobremaneira, para a formação de critérios básicos para o desenvolvimento e melhoria de estratégias destinadas à preservação deste peculiar grupo de mamíferos da fauna brasileira.

Agradecimentos.- Os autores agradecem à FAPEMIG (CVZ PPM-00359/ 14) e à Capes (PROAP) pelo apoio financeiro à pesquisa.

\section{REFERÊNCIAS}

Anderson M.E., Paparo A.A. \& Martan J. 1979. Paraformaldehyde-induced fluorescence as a histochemical test for 5-hidroxytryptamine in the epididymis of the opossum. J. Anat. 129:141-149.

Amann R.P. 1987. Function of the epididymis in bulls and rams. J. Reprod. Fertil. 34(Suppl.):115-131.

Barbour R.A. 1977. Anatomy of marsupials, p.237-242. In: Stonehouse B. \& Gilmore D. (Eds), The Biology of Marsupials. Vol.15. MacMillan Press, London.

Barnes R.D. 1977. Reproductive system, p.404-412. In: Ibid. (Ed.), The Special Anatomy of Marmosa robinsoni. Vol.7. Academic Press, New York.

Barnett C.H. \& Brazenor C.W. 1958.The testicular rete mirabile of marsupials. Aust. J. Zool. 6:27-32.

Barros M.A., Miglino M.A., Martins J.F.P., Ambrosio C.E., Verechia F.T., Rosa R.A. \& Carvalho A.F. 2003. Morfologia do sistema reprodutor masculino do gambá (Didelphis sp.). Revta Bras. Reprod. Anim. 27:225-226.

Barros M.A., Panattoni Martins J.F., Samoto V.Y., Oliveira V.C., Gonçalves N., Furlaneto Mançanares C.A., Vidane A., Carvalho A.F., Ambrosio C.E. \& Miglino M.A. 2013. Marsupial morphology of reproduction: South America opossum male model. Microsc. Res. Tech.76:388-397. 
Brown D. \& Montesano R. 1981. Membrane specialization in the rat epididymis. II. The clear cell. Anat. Rec. 201:477-483.

Biggers J.D. \& Creed R.F.S. 1962. Conjugated spermatozoa of the North American opossum. Nature 196:1112-1113.

Biggers J.D., Creed R.F.S. \& Lamater E.D. 1964. Conjugated spermatozoa in American marsupials. J. Reprod. Fertil. 6:324.

Biggers J.D. 1966. Reproduction in male marsupials, p.251-280. In: Rowlands I.W. (Ed.), Comparative Biology of Reproduction in Mammals. Academic Press, London.

Chase E.B. 1939. The reproductive system of the male opossum, Didelphis virginiana Kerr, and its experimental modification. J. Morphol. 65:215239.

Chiarini-Garcia H. 1991. Inclusão de material biológico em resinas plásticas. Departamento de Morfologia, Instituto de Ciências Biológicas, UFMG, Belo Horizonte. 21p.

Costa S.F., José H. \& Nogueira J.C. 1994. Morfologia do sistema genital masculino de Metachirus nudicaudatus, Didelphidae-Marsupialia. Anais Reunião da Sociedade Brasileira para o Progresso da Ciência, Vitória, p.761. (Resumo)

Costa S.F. 1995. Morfologia do sistema genital masculino de Metachirus nudicaudatus (Geoffrow, 1803), Didelphilidae, Marsupualia. Dissertação de Mestrado em Morfologia, Instituto de Ciências Biológicas, Universidade Federal de Minas Gerais, Belo Horizonte, MG. 128p.

Costa S.F., José H. \& Nogueira J.C. 1996. Aspectos anatômicos do sistema genital masculino do jupati, Metachirus nudicaudatus. Bios 4:31-36.

Cowper W. 1704. Giving an account of the anatomy of those parts of a male opossum that differ from the female. Philosophic. Transact. Royal Soc. London B, Biol. Sci. 24:1576-1590.

Cummins J.M., Temple-Smith P.E. \& Renfree M.B. 1986. Reproduction in the male Honey Possum (Tarsipes rostratus), Marsupialia: the epididymis. Am. J. Anat. 177:385-401.

Davis R.J., Langfore G.A. \& Kirby P.J. 1970. The testicular capsule, p.282338. In: Johnson A.D., Gomes W.R. \& Vandemark N.L. (Eds), The Testis. Academic Press, New York.

Dawson T.J., Finch E., Freedman L., Hume I.D., Renfree M.R. \& TempleSmith P.D. 1988. Morphology and physiology of the metatheria. Fauna of Australia 1:17.

Dym M. \& Romrell L.J. 1975. Intraepitelial lymphocytes in the male reproductive tract of rats and rhesus monkeys. J. Reprod. Fertil. 42:1-7.

Godinho H.P. \& Setchell B.P. 1975. Total and capillary blood flow through the testes of anaesthetized rams. J. Physiol. 251:19-20.

Godinho H.P., Cardoso F.M. \& Nogueira J.C. 1977. Blood supply to the testis of a Brazilian marsupial (Didelphis azarae) and its abdominotesticular temperature gradiente. Acta Anatomica 99:204-208.

Gomori G. 1937. Silver impregnation of reticulum in paraffin sections. Am. J. Pathol. 13:993.

Harding H.R., Carrick F.N. \& Shorey C.D. 1979. Special features of sperm structure and function in marsupials, p.289-303. In: Fawcett D.W. \& Bedford J.M. (Eds), The Spermatozoon. Urban and Schwarzenberg, Baltimore.

Harrison, R.G. 1949. The comparative anatomy of the blood-supply of the mammalian testis. p. 325-343. In: Proceedings of the Zoological Society of London, London.

Heddle R.M.L. \& Guiler E.R. 1970. The form and function of the testicular rete mirabile of marsupials. Comp. Biochem. Physiol. 35:415-425.

Hoffer A.P., Hamilton D.W. \& Fawcett D.W. 1973. The ultrastructure of the principal cells and intraepithelial leucocytes in the initial segment of the rat epididymis. Anat. Rec. 175:169-202.

Hunsaker II, D. 1977. The biology of Marsupials. Academic Press, New York.

Jones R.C., Hinds L.A. \& Tyndale-Biscoe C.H. 1984. Ultrastructure of the epididymis of the tammar, Macropus eugenii, and its relationship to sperm maturation. Cell Tissue Res. 237:525-535.

Kelce, W.R., Krause, W.J. \& Garjam, V.K. 1987. Unique regional distribution of -3. Ketosteroid-5-oxidoreductase and associated epididymal morphology in the marsupial, Didelphis virginiana. Biol. Reprod. 37: 403-420.
Kirsch, J. A. W. 1979. Les marsupiaux. La Recherche. 10: 108-116.

Ladman J.A. 1967. The fine structure of the ductuli efferent of the opossum. Anat. Rec. 157: 559-576.

Leeson T.S. \& Cookson F.B. 1974. The mammalian testicular capsule and its muscle elements. J. Morphol. 144:237-254.

Lee C.S. \& O'shea J.D. 1977. Observations on the vasculature of the reproductive tract in some Australian marsupials. J. Morphol. 154:95-144.

Lev R. \& Spicer S.S. 1964. Specific staining of sulphate groups with Alcian Blue at low pH. J. Histochem. Cytochem. 12:309.

Lillie R.D. 1958. Acetylation and nitrosation of tissue amines in histochemistry. J. Histochem. Cytochem. 6:352-361.

Lillie R.D. \& Fullmer H.M. 1976. Histopathologic technic and practical histochemistry. 4th ed. McGraw Hill, New York.

Lima J.M.N., Santos A.C., Viana D.G., Bertassli B.M., Lobo L.M., Oliveira V.C., Briani D.C., Costa G.M., Assis Neto A.C., Ambrosio C.A., Carvalho A.F. \& Mançanares C.A.F. 2013. Morphological study of the male genital organs of Gracilinanus microtarsus: estudo morfológico dos órgãos genitais masculinos em Gracilinanus microtarsus. Braz. J. Vet. Res. Anim. Sci. 50:447-456.

Lin M. \& Rodger J.C. 1999. Acrosome formation during sperm transit through the epididymis in two marsupials, the tammar wallaby (Macropus eugenii) and the brush tail possum (Trichosurus vulpecula). J. Anat. 194:223-232.

Lison L. 1960. Histochimie at cytochimie animals: principes et methods. $3^{a}$ ed. Gauthier-Villars, Paris.

Machado C.R.S., Calixto S.L. \& Ladosky W. 1982. Morphological and physiological factors involved in the contractility of the spermatic cord and ductus deferens of the opossum (Didelphis albiventris). J. Reprod. Fertil. 65:275-280

Martan J., Hruban Z. \& Slesers A. 1967. Cytological studies of the ductuli efferents of the opossum. J. Morphol. 121:81-102.

Martinelli P.M. 1990. Morfologia do sistema genital masculino de Marmosa cinerea Temminck, 1824 (Didelphidae-Marsupialia). Dissertação de Mestrado em Morfologia, Instituto de Ciências Biológicas, Universidade Federal de Minas Gerias, Belo Horizonte, MG. 141p.

Martinelli, P.M. \& Nogueira, J.C. 1992.Epididymal morphology in the South American Marsupial Marmosa cinerea Temminck, 1824. Rev. Bras. Ciênc. Morfol. 9: 26-31.

McManus J.F.A. 1946. Histological demonstration of mucin after periodic acid. Nature 158:202.

Mowry R.W. 1956. Alcian Blue technique for the histochemical study of acidic carbohydrates. J. Histochem. Cytochem. 4:407.

Noden D.M. \& De Lahunta A. 1985. Derivates of the intermediate mesoderme: reproductive organs, p.322-342. In: Ibid. (Eds), The Embryology of Domestic Animals. Williams and Wilkins, Baltimore.

Nogueira J.C., Godinho H.P. \& Cardoso F.M. 1977. Microscopic anatomy of the scrotum, testis with its excurrent ducts system and spermatic cord of Didelphis azarae. Acta Anatomica 99:209-219.

Nogueira J.C. \& Ribeiro R.D. 1980. A simplified Weigert's method for staining elastic fiber. Arqs Esc. Vet. UFMG 1:333-335.

Nogueira J.C. \& Redins C.A. 1987. Submicroscopic study of the tunica propria of the seminiferous tubules of the Brazilian White-belly opossum (Didelphis albiventris). Anatomischer Anzeiger 163:349-357.

Nogueira J.C. \& Redins C.A. 1988. Fine structure of macrophages in the testicular interstitial tissue of the white-belly opossum Didelphis albiventris. Microscopia Electrônica y Biologia Celular12:23-34.

Nogueira J.C. \& Redins C.A. 1989. Modificações sazonais na ultra-estrutura das glândulas bulbo-uretrais do gambá Didelphis albiventris (Marsupialia). Anais $12^{\circ}$ Colóquio da Sociedade Brasileira de Microscopia Eletrônica, Caxambú,1:163-164.

Nogueira J.C., Silva M.N.F. \& Camara B.G.O. 1999. Morphology of the male genital system of the bushy-tailed opossum Glironia venusta Thomas, 1912 (Didelphimorphia, Didelphidae). Mammalia 63:231-236.

Nogueira J.C. \& Castro C.S.A. 2003. The biology of carnivorous marsupials, p.183-204. In: Jones M.E., Dickman C.R. \& Archer M. (Eds), Predators with Pouches. CSIRO, Australia. 
Nogueira J.C., Castro C.S.A., Câmara E.V.C. \& Câmara B.G.O. 2004. Morphology of the male genital system of Chironectes minimus and comparison to other didelphid marsupials. J. Mammalogy 85:834-841.

Nogueira J.C. 2012. Morfologia do sistema genital masculino de marsupiais brasileiros, p.217-244. In: Cáceres N.C. (Ed.), Os Marsupiais do Brasil: biologia, ecologia e conservação. $2^{\underline{a}}$ ed. Editora UFMS, Campo Grande, MS.

Orsi A.M., Ferreira A.L. \& De Mello V.R. 1979. Sobre a morfologia da rede testicular (rete testis) do gambá (Didelphis azarae). Ciência e Cultura 31:1029-1031.

Orsi A.M., Ferreira A.L., De Mello V.R., Valente M.M. \& Moreira J.E. 1980a. Morfologia del estroma conectivo del epidídimo de un marsupial sudamericano (Didelphis azarae). Zentralblatt für Veterinärmedizin Reihe C, Anatomie, Histologie, Embryologie 9:296-301.

Orsi A.M., De Mello V.R., Ferreira A.L., De Mello V.R. \& Valente M.M. 1980b. Morfologie des céllules epithéliales du canal de l'epididyme de l'opossum (sarigue) sud-américain (Didelphis azarae). Anatomischer Anzeiger 148:7-13.

Orsi A.M., Ferreira A.L., De Mello V.R. \& Oliveira M.C. 1981. Regional histology of the epididymis in the South American opossum: light microscope study. Anatomischer Anzeiger 150:521-528.

Orsi A.M. 1982. Aspectos estruturais e histofisiológicos da via seminífera em mamíferos. II. Morfologia dos dúctulos eferentes e do epidídimo. Acta Biológica Leopodensia 4:29-34.

Patten B.M.1984. Embryology of the pig. 3rd ed. Blakiston Company, Philadelphia. 352p.

Queiroz G.F. 1991. Estudo morfológico e quantitativo da atividade testicular do gambá Didelphis albiventris (Marsupialia). Tese de Doutorado em Morfologia, Instituto de Ciências Biológicas, UFMG, Belo Horizonte. 83p.

Queiroz G.F. \& Nogueira J.C. 1992. Duration of the cycle of the seminiferous epithelium and quantitative histology of the testis of the South American white-belly opossum (Didelphis albiventris), Marsupialia. Reprod. Fertil. Develop. 4:213-222.

Rodger J.C. 1982. The testis and its excurrent ducts in American Caenolestid and Didelphid marsupials. Am. J. Anat. 163:269-282.

Romer, A. S. 1985. Anatomia Comparada dos Vertebrados. Atheneu, São Paulo.

Ribeiro M.G. 1981. Aspectos anatômicos e histologia do sistema genital masculino da cuíca Philander opossum (Linnaeus, 1758) DidelphidaeMarsupialia. Dissertação de Mestrado em Morfologia, Instituto de Ciências Biológicas, UFMG, Belo Horizonte. 147p.

Ribeiro, M. G. \& Nogueira, J. C. 1991. Histologia da pele escrotal e túnica vaginal da cuíca Philander opossum (Linnaeus, 1758)-Didelphidae-Marsupialia. Rev. Bras. Zool. 7: 245-250.

Ribeiro M.G. \& Nogueira J.C. 1982. Aspectos anatômicos do sistema genital masculino da cuíca Philander opossum (Linnaeus, 1758), DidelphidaeMarsupialia. Lundiana 2:57-69.

Santos R.C., Barbosa F.O., Cruz M.S., Costa S.F., Teófilo T.S. \& Nogueira J.C. 2011. Aspectos morfológicos do epidídimo e do ducto deferente do Ju- pati (Metachirus nudicaudatus). Anais 24ํㅡㄹ Congresso de Iniciação Científica da UFLA, Universidade Federal de Lavras, p.462.

Setchell B.P. 1977. Reproduction in male marsupials, p.411-457. In: Stonehouse B. \& Gilmore D. (Eds), The Biology of Marsupials. MacMillan Press, London.

Sharman, G.B. 1970. Reproductive physiology of marsupials. Science. 167:1221-1228.

Taggart D.A., Johnson J.L., O’Brien H.P. \& Moore H.D. 1993. Why do spermatozoa of American marsupials form pairs? A clue from the analysis of sperm-pairing in the epididymis of the grey short-tailed opossum Monodelphis domestica. Anat. Rec. 236:465-478.

Taggart D.A. \& Temple-Smith P.D. 1989. Structural features of the epididymis in a dasyurid marsupial, Antechinus stuartii. Cell Tissue Res. 258:203-210.

Temple-Smith P.D. \& Bedford J.M. 1976. The features of sperm maturation in the epididymis of a marsupial, the brush tailed possum, Trichosurus vulpecula. Am. J. Anat. 147:471-500.

Temple-Smith P.D. 1984a. Reproductive structures and strategies in male opossums and gliders, p.89-106. In: Smith A.P. \& Hume I.D. (Eds), Possums and Gliders. Surrey Beaty and Sons, Sidney.

Temple-Smith, P.D. 1984b. Phagocytosis of sperm cytoptasmic droplets by a specialized region in the epididymis of the brushtailed possum, Trichosus vulpecula. Biol. Reprod. 30:707-720.

Temple-Smith, P.D. 1987. Sperm structure and marsupial philogeny. p. 171-193. In: Archer, A.M.(ed.). Possums and opossums. Surrey Beaty \& Sons, Sydney.

Temple-Smith P.D. \& Taggart D.A. 1990. On the generative organs of the Koala (Pharcolarctos cinereus): an update, p.33-54. In: Lee A.K., Handassyde K.A. \& Sanson G.D. (Eds), Biology of the Koala. Surrey Beatty and Sons, Sidney.

Tyndale-Biscoe C.H. \& Renfree M. 1987. Male anatomy and spermatogenesis, p.124-171. In: Tyndale-Biscoe C.H. \& Renfree M. (Eds), Reproduction Physiology of Marsupials. Cambridge University Press, Cambridge.

Viotto M.J.S., Orsi A.M., Dias S.M., Fernandes W.A. \& Camilli J.A. 1988. Histologia regional do epidídimo do gato (Felis domestica L.). Ciência e Cultura 40:1195-1199.

Wensing C.J.C. \& Dukstra G. 1981. The morphological relation between the testicular artery and the pampiniform plexus in the spermatic cord. Acta Morphologica Neerlando-Scandinavica 19:162.

Woolley P.A. \& Scarlett G. 1984. Observations on the reproductive anatomy of male Tarsipes rostratus (Marsupialia: Tarsipedidae), p.445-450. In: Smith A.P. \& Hume I.D. (Eds), Possums and Gliders. Surrey Beaty and Sons, Sidney.

Woolley P.A. 1987. The seminiferous tubules, rete testis and efferent ducts in Didelphidae, Caenolestidae and Mecrobiotheriidae marsupials, p.217-227. In: Archer A.M. (Ed.), Possums and Opossums. Surrey Beaty and Sons, Sidney.

Yasuma A. \& Ichikawa T. 1953. Ninhydrin-Schiff and Alloxcan-Schiff staining: a new histochemical staining method for protein. J. Lab. Clin. Med. 41:296-299. 